\title{
Gene expression profiling of peripheral blood mononuclear cells in the setting of peripheral arterial disease
}

\author{
Rizwan Masud ${ }^{\dagger}$, Khader Shameer $^{\dagger}$, Aparna Dhar, Keyue Ding and Iftikhar J Kullo
}

\begin{abstract}
Background: Peripheral arterial disease (PAD) is a relatively common manifestation of systemic atherosclerosis that leads to progressive narrowing of the lumen of leg arteries. Circulating monocytes are in contact with the arterial wall and can serve as reporters of vascular pathology in the setting of PAD. We performed gene expression analysis of peripheral blood mononuclear cells (PBMC) in patients with PAD and controls without PAD to identify differentially regulated genes.

Methods: PAD was defined as an ankle brachial index $(A B I) \leq 0.9(n=19)$ while age and gender matched controls had an $A B I>1.0(n=18)$. Microarray analysis was performed using Affymetrix HG-U133 plus 2.0 gene chips and analyzed using GeneSpring GX 11.0. Gene expression data was normalized using Robust Multichip Analysis (RMA) normalization method, differential expression was defined as a fold change $\geq 1.5$, followed by unpaired MannWhitney test $(P<0.05)$ and correction for multiple testing by Benjamini and Hochberg False Discovery Rate. Metaanalysis of differentially expressed genes was performed using an integrated bioinformatics pipeline with tools for enrichment analysis using Gene Ontology (GO) terms, pathway analysis using Kyoto Encyclopedia of Genes and Genomes (KEGG), molecular event enrichment using Reactome annotations and network analysis using Ingenuity Pathway Analysis suite. Extensive biocuration was also performed to understand the functional context of genes.

Results: We identified 87 genes differentially expressed in the setting of PAD; 40 genes were upregulated and 47 genes were downregulated. We employed an integrated bioinformatics pipeline coupled with literature curation to characterize the functional coherence of differentially regulated genes.

Conclusion: Notably, upregulated genes mediate immune response, inflammation, apoptosis, stress response, phosphorylation, hemostasis, platelet activation and platelet aggregation. Downregulated genes included several genes from the zinc finger family that are involved in transcriptional regulation. These results provide insights into molecular mechanisms relevant to the pathophysiology of PAD.
\end{abstract}

Keywords: Peripheral arterial disease, Gene expression, Microarray analysis, Vascular disease, Biomarkers

\section{Introduction}

Peripheral arterial disease (PAD) affects more than eight million adults in the United States and is associated with significant mortality and morbidity [1-6]. PAD is a surrogate for diffuse atherosclerosis but is often underdiagnosed $[4,6]$. Identification of differentially regulated genes in the setting of PAD may lead to potential biomarkers for the

\footnotetext{
* Correspondence: kullo.iftikhar@mayo.edu

+ Contributed equally

Division of Cardiovascular Diseases, Mayo Clinic, Rochester MN 55905, USA
}

earlier detection and prognostication of this disease and provide insights into its pathophysiology.

Gene expression analysis of peripheral blood mononuclear cells (PBMC) in asymptomatic individuals has previously revealed individual genetic variation and differentially regulated expression patterns $[7,8]$. Circulating peripheral blood cells have been used to examine differentially regulated genes in several cardiovascular disorders. For example, gene expression profiling studies of blood cells have identified differentially regulated genes and pathways in hypertension [9], coronary artery

\section{Biomed Central}


disease [10,11] and ischemic stroke [1,10,12-16]. However, genes differentially expressed in PBMC in the setting of PAD have yet to be identified. Circulating PBMC are in contact with the arterial wall and may be useful in investigating molecular mechanisms relevant to PAD. We therefore performed gene expression analysis to identify differentially expressed genes in PBMC in the setting of PAD.

\section{Materials and methods}

\section{Participant recruitment and sample characteristics}

The Mayo Clinic Institutional Review Board approved the study and all participants provided written informed consent. The participants were recruited from the Mayo non-invasive vascular laboratory and PAD was defined as an ankle brachial index $(\mathrm{ABI}) \leq 0.9(\mathrm{n}=19)$ while age and gender matched controls had an ABI > $1.0(n=18)$. ABI was measured in both the lower extremities and the lower of the two values was recorded for the analysis [17]. Individuals with poorly compressible arteries or aortic aneurysmal disease were excluded.

\section{Isolation of peripheral blood mononuclear cells (PBMC) and RNA isolation}

PBMC were isolated by density gradient centrifugation by layering the blood samples over histopaque (SigmaAldrich, St. Louis, MO),[18]. In brief, $18 \mathrm{ml}$ of whole blood was mixed with equal amount of PBS (Bio-Rad, Hercules, CA), and layered over $12 \mathrm{ml}$ of histopaque 1077 (used for cell separation). The PBMC layer was removed, washed, and centrifuged twice with Hank's Balanced Salt Solution (HBSS) (Sigma-Aldrich, St. Louis, MO). The pellet formed after double centrifugation was re-suspended in Complete RPMI-10 medium. The cells were counted using a hemocytometer and processed for RNA isolation using RNeasy Plus Mini Kit (Qiagen, Valencia, CA), and additionally with TRIzol (Invitrogen, Carlsbad, CA). For the RNeasy kit, PBMCs were disrupted and homogenized using RLT buffer (Qiagen, Valencia, CA). The RNeasy kit includes gDNA eliminator spin column for the removal of genomic DNA from the sample, allowing subsequent purification of RNA. The flow through from the gDNA column was mixed with ethanol and placed on the RNeasy spin column. This spin column uses a silica gel based membrane for effective binding and purification of RNA. Total RNA was eluted in RNase free water, quantified using NanoDrop 1000 (Thermo Scientific, Wilmington, DE) and stored at $-80^{\circ} \mathrm{C}$.

\section{Microarray analysis}

RNA quantity and quality were assessed using Agilent 2100 Bioanalyzer (Agilent, Santa Clara, CA); $100 \mathrm{ng}$ of total RNA was used for generation of biotin labeled cRNA using Affymetrix Two-Cycle cDNA Synthesis Kit
(Affymetrix, Santa Clara, CA). After the first cycle, in vitro transcription-based (IVT) amplification of cRNA was carried out using MEGAscript T7 kit (Applied Biosystems/Ambion, Austin TX). With the second cycle cDNA synthesis, biotin labeled cRNA was generated using the Affymetrix IVT labeling Kit. The labeled cRNA was cleaned, quantified and after fragmentation, hybridized to Affymetrix HG-U133 Plus2.0 GeneChips. The chips were stained with streptavidin phycoerythrin and biotinylated antibody and washed at an Affymetrix Fluidics station 450. The GeneChips were scanned and data extracted using GeneChip scanner 3000 (Affymetrix, Santa Clara, CA) and the raw data file formats were generated using GeneChip operating software (GCOS).

\section{Data processing and statistical analysis}

Raw gene expression data were analyzed using the GeneSpringGx 11.0 software (Agilent ${ }^{\circledR}$ Technologies, Santa Clara, CA). All samples were normalized and summarized by Robust Multichip Analysis (RMA) normalization method, which includes background correction, normalization and calculation of expression values [19]. Baseline was set to median for all samples, where median of the log-transformed value of each probe from all samples was calculated and this value was subtracted from all samples. Probes were filtered and eliminated on expression level as part of quality control (QC) and probes with expression values $<20 \%$ were excluded. Of the remaining probes, those with a 1.5 -fold-change difference between the groups underwent unpaired MannWhitney test and multiple testing correction was performed using Benjamini and Hochberg False Discovery Rate (FDR). Following statistical analysis and probe mapping, 47 genes were upregulated and 39 genes were downregulated. Differentially expressed probes were clustered using MultiExperiment Viewer (MeV v4.5 [20]) (Figure 1). The clustering figure shows a distinct pattern of upregulated and downregulated probes in cases when compared to the controls.

\section{Validation using real-time PCR}

To validate our findings from gene expression analysis, we performed real-time PCR of the Syntaxin 11 (STX11), a gene not previously associated with PAD. STX11 is a component of t-SNARE complex and involved in endocytic vesicular transport, regulate protein transport among late endosomes and the transGolgi network and may have functional or regulatory role in vascular diseases. RNA derived from PAD and control samples was converted to cDNA by reverse transcription using Transcriptor First Strand cDNA Synthesis kit (Roche, OH, USA) and used immediately for real-time PCR. The FASTA sequence of each gene of interest was obtained using NCBI nucleotide search 


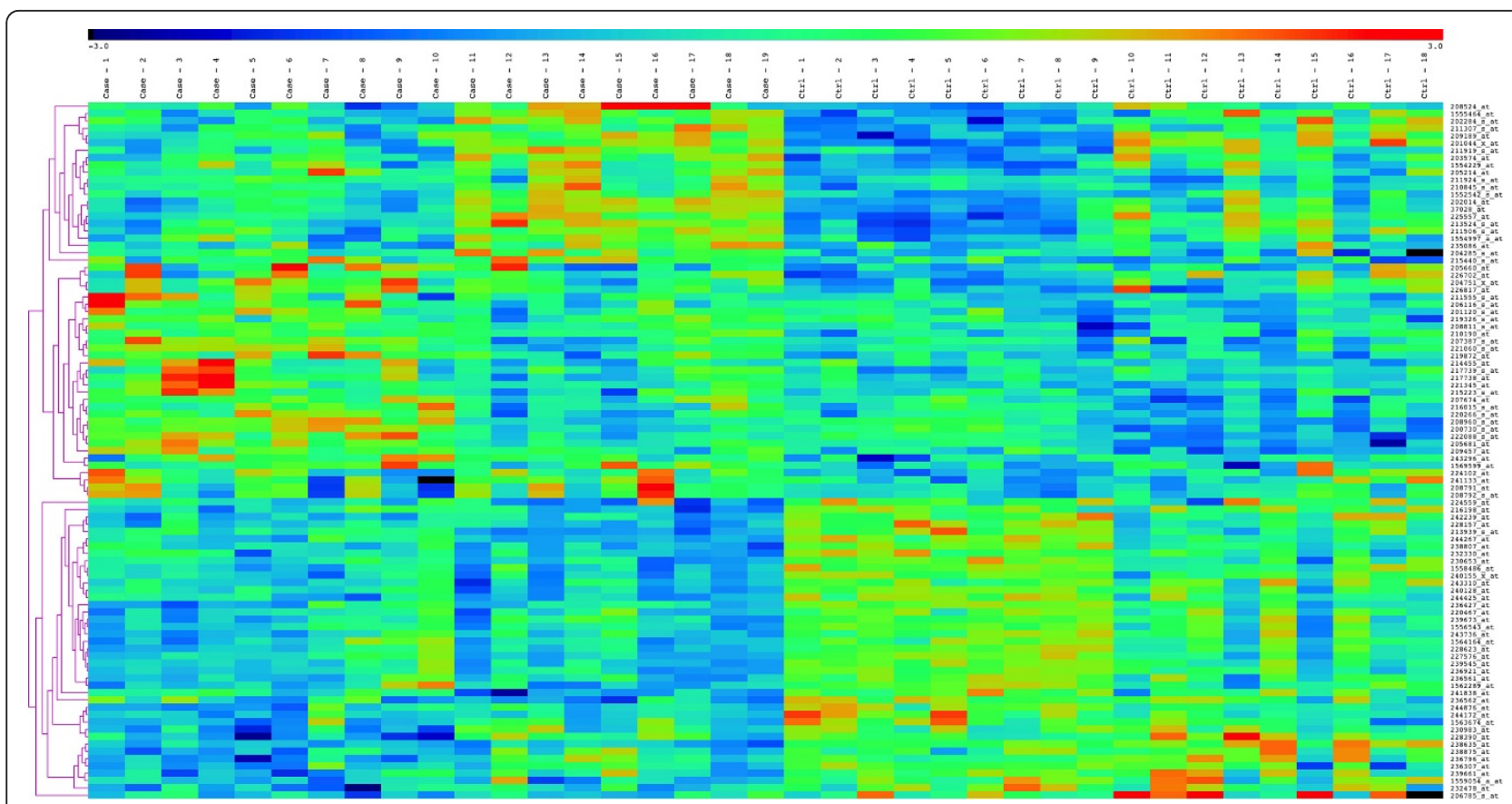

Figure 1 Hierarchical clustering of differentially regulated genes in the setting of PAD. Clustering was performed using hierarchical clustering algorithm with Euclidean distance and average linkage clustering method.

to design the primers http://www.ncbi.nlm.nih.gov/nuccore. This FASTA sequence was used as query to search in NCBI Primer BLAST http://www.ncbi.nlm.nih.gov/ tools/primer-blast/index.cgi?LINK_LOC=BlastHome. Primers pairs were selected based on primer length (18$30 \mathrm{bp}), \mathrm{GC}$ content, melting temperature $\left(\mathrm{T}_{\mathrm{m}}=59-60^{\circ} \mathrm{C}\right)$, and product size. Primers were selected that scan exonexon junctions. BLAST was used to check the specificity of primers to the gene of interest. PAGE-purified oligos (Integrated DNA Technologies, IA, USA) were used for real-time PCR. Primer sequences are available from the corresponding author upon request. Real-time PCR assay was performed using the LightCycler 480 instrument (Roche) and the LightCycler 480 SYBR Green I Master kit and protocol. Each sample was assayed in duplicate for the genes of interest as well as $ß$-actin $(A C T B)$ as a housekeeping gene for normalization. Samples were assayed in 384 -well plates with a $20 \mu \mathrm{L}$ reaction volume. (10 uL master mix (FastStart Taq DNA polymerase, reaction buffer, dNTPs, SYBR Green I dye, and $\mathrm{MgCl}_{2}$ ), 3uL PCR-grade water, $1 \mathrm{uL}$ each $2 \mathrm{nM}$ primer, and $5 \mathrm{uL}$ (32 ng) cDNA template. Raw $\mathrm{Cp}$ values were calculated using the Abs Quant $/ 2^{\text {nd }}$ derivative max option in Roche's LightCycler 480 software (release 1.5.0 SP3).

\section{Functional annotation of differentially regulated genes using in-silico approach}

To assess the functional repertoire of differentially expressed genes we adopted a multi-tiered bioinformatics annotation pipeline with functional enrichment calculations, pathway and molecular event analysis, biological network analysis and biocuration. Statistically significant genes and annotations were used as pointers to perform literature curation to derive biological role of genes differentially regulated in the setting of PAD. Preliminary functional annotations of differentially regulated genes were derived using BioGPS [21].

GO term enrichment analysis was performed using DAVID v6.7 [22,23]. As no single annotation resource provides information about all available biological pathways, we used two different pathway databases (Reactome v36.2 [24] and Kyoto Encyclopedia of Genes and Genomes (KEGG) [25]) to identify the biological pathways mediated by differentially expressed genes. Reactome based pathway enrichment analysis was performed using Reactome Pathway Analysis tool http://www.reactome.org/ReactomeGWT/entrypoint.html\#PathwayAnalysisDataUploadPage. This two-fold approach was useful in finding several relevant pathways from two different pathway analyses. Ingenuity Pathway Analysis ${ }^{\circledR}$ suite (IPA v9.0 - 3211, http://www.ingenuity.com) was used to understand functional networks involved in the gene sets. IPA-Tox ${ }^{\circledR}$, a data analysis routine within IPA that assess potential toxicity with various compounds using toxicogenomics data was also used to interpret the functional context of differentially regulated genes. Finally, to understand the functional context and biological significance of differentially expressed genes relevant to PAD, 
scientific literature was curated using Gene Related InFormation (GeneRIF http://www.ncbi.nlm.nih.gov/projects/GeneRIF) and 'related articles by PubMed' in the 'Entrez Gene' http://www.ncbi.nlm.nih.gov/gene page.

\section{Results}

Patient characteristics are summarized in Table 1. The PBMC from patients with PAD differentially expressed 87 genes involved in immune response, inflammation, phosphorylation, signal transduction, platelet aggregation, vitamin metabolism, hemostasis, oxidative stress and transcriptional regulation.

\section{Differentially expressed genes}

Based on the comparisons of cases and controls, after initial data filtering and at a 1.5 fold change, 95 probes were differentially expressed $(P<0.05$; $)$ (Table 2$)$. A subset of probes was not annotated in Affymetrix annotation files. We obtained enhanced probe mapping by combining results from multiple probe mapping tools AILUN [26], BioMart [27] and GATExplorer [28]. Final probe mapping was performed using the union of mapped results obtained from these methods. NCBIGene and UCSC genome browser [29] were also consulted for annotation and integration of probe and gene related information. Statistically significant probes, mapped genes, $P$-value, fold change absolute (FCA) and directions of expression (regulation) are summarized in Table 2. Ten downregulated probes were not mapped to a valid gene using the probe mapping approach that we employed and were manually mapped using Ensembl v58 annotations [30]. For example probe "241838_at" (FCA 1.53) was not mapped to a valid gene using our

Table 1 Sample characteristics

\begin{tabular}{|c|c|c|c|}
\hline \multirow[t]{2}{*}{ Characteristic } & \multicolumn{2}{|l|}{ Samples } & \multirow{2}{*}{$\begin{array}{l}P \text { - } \\
\text { value }\end{array}$} \\
\hline & $\begin{array}{l}\text { Cases }(n= \\
19)\end{array}$ & $\begin{array}{l}\text { Controls }(n= \\
18)\end{array}$ & \\
\hline Age, years & $69.57 \pm 9.18$ & $66.88 \pm 9.44$ & 0.54 \\
\hline Men, \% & $13(68 \%)$ & $13(72 \%)$ & 0.99 \\
\hline Ever smoker, \% & 17 (89\%) & $12(66 \%)$ & 0.15 \\
\hline $\mathrm{BMI}, \mathrm{kg} \cdot \mathrm{m}^{-2}$ & $28.53 \pm 5.25$ & $30.6 \pm 5.99$ & 0.27 \\
\hline Systolic BP, mm Hg & $139.2 \pm 23.27$ & $132.4 \pm 20.1$ & 0.47 \\
\hline Diastolic BP, mm Hg & $74.2 \pm 11.66$ & $80.1 \pm 12.3$ & 0.15 \\
\hline HDL cholesterol, mg/dl & $44.12 \pm 8.59$ & $49.7 \pm 15$ & 0.38 \\
\hline Hypertension, \% & $17(89.4 \%)$ & $13(72 \%)$ & 0.18 \\
\hline Diabetes, \% & $5(26 \%)$ & $4(22 \%)$ & 0.69 \\
\hline $\begin{array}{l}\text { Lipid-lowering medication, } \\
\%\end{array}$ & $11(57 \%)$ & $12(66 \%)$ & 0.85 \\
\hline Ankle-brachial index & $0.48 \pm 0.20$ & $1.12 \pm 0.07$ & $<0.001$ \\
\hline WBC count, $\mu \mathrm{L}$ & $8.03 \pm 2.34$ & $7.26 \pm 1.10$ & 0.18 \\
\hline
\end{tabular}

Values are expressed as either 'mean \pm standard deviation' or as ' $\mathrm{n}(\%)$ ' probe mapping strategy but using Ensembl v58 [30] the probe was mapped to a non-coding transcript RP1167A14.2. One probe "243310_at" could not be mapped to any known gene using the probe mapping databases or Ensembl annotations.

\section{Real-time quantitative PCR analysis}

The raw data ( $\mathrm{Cp}$ values) were read in the $\mathrm{R}$ software (version 2.12.0) and the non-parametric Mann-Whitney unpaired test was used for analyzing the target gene STX11 in reference to the housekeeping gene ACTB. Cp values of $A C T B$ were used for normalization. Using RTqPCR, STX11 was successfully amplified and confirmed to have significant differential expression $(P=0.036)$.

\section{In-silico analysis of differentially expressed genes}

The differentially expressed genes were analyzed using a bioinformatics pipeline to understand the functional role of the genes. A flow-chart of the multi-tiered bioinformatics approach is provided in Figure 2. Multiple resources were integrated in the pipeline to provide a cohesive view of biological functions and pathways associated with the differentially expressed genes. Results from enrichment analysis using GO terms (Tables 3 and 4), pathway analysis using KEGG pathways (Table 5) and enrichment analysis of molecular event analysis using Reactome annotations (Table 6) are provided. Interactions within the differentially regulated genes were identified using biological network analysis utilities in IPA (Tables 7 and 8). Brief description of methodology and results from various approaches are provided.

\section{GO terms associated with differentially expressed genes}

$\mathrm{GO}$ enrichment analysis was performed using GO Fat (collection of broadest GO terms curated from GO annotations dataset) based annotations using DAVID $[23,31]$. The background was defined as the 'Human Genome U133 Plus 2' annotation and the differentially expressed genes from the study were input for assessing the enrichment. The upregulated and downregulated probe set identifiers were used as input and enrichment was analyzed separately and the results provided for the significantly enriched terms using Fisher's exact test using the EASE modification $(P<0.05)$ and multiple testing correction was performed using BenjaminiHochberg FDR method. The P-value for each GO term reflects the enrichment in frequency of that GO term in the input entity list (differentially regulated probe set identifiers) relative to all entities in the background list (probe identifiers in Human Genome U133 Plus 2).

Among different GO terms of upregulated genes, several enriched terms in 'biological process' (Table 3 and Additional file 1: Table S1) categories were related to molecular mechanisms associated with inflammation 
Table 2 Differentially expressed probes/genes in the setting of peripheral arterial disease

\begin{tabular}{|c|c|c|c|c|}
\hline Upregulated Probe ID & Gene name (HUGO) & Gene symbol & $P$-value & FCA \\
\hline 219326_s_at & UDP-GIcNAc:betaGal beta-1,3-N-acetylglucosaminyltransferase 2 & B3GNT2 & 0.032 & 1.53 \\
\hline 205681_at & $\mathrm{BCL2}$-related protein A1 & $B C L 2 A 1$ & 0.008 & 1.73 \\
\hline 215440_s_at & brain expressed, $X$-linked 4 & BEX4 & 0.004 & 1.50 \\
\hline 1554229_at & chromosome 5 open reading frame 41 & C5orf41 & 0.004 & 1.51 \\
\hline 202284_s_at & cyclin-dependent kinase inhibitor 1A (p21, Cip1) & CDKN1A & 0.024 & 1.62 \\
\hline 208791_at & clusterin & CLU & 0.029 & 1.84 \\
\hline 208792_s_at & clusterin & $C L U$ & 0.038 & 1.83 \\
\hline 226702_at & cytidine monophosphate (UMP-CMP) kinase 2, mitochondrial & CMPK2 & 0.039 & 1.54 \\
\hline 225557_at & cysteine-serine-rich nuclear protein 1 & CSRNP1 & 0.032 & 1.57 \\
\hline 211919_s_at & chemokine (C-X-C motif) receptor 4 & CXCR4 & 0.039 & 1.59 \\
\hline 208811_s_at & DnaJ (Hsp40) homolog, subfamily B, member 6 & DNAJB6 & 0.004 & 1.53 \\
\hline 204751_x_at & desmocollin 2 & DSC2 & 0.007 & 1.68 \\
\hline 226817_at & desmocollin 2 & DSC2 & 0.007 & 1.99 \\
\hline 201044_x_at & dual specificity phosphatase 1 & DUSP1 & 0.043 & 1.94 \\
\hline 209457_at & dual specificity phosphatase 5 & DUSP5 & 0.008 & 1.56 \\
\hline 219872_at & family with sequence similarity 198 , member B & FAM198B & 0.003 & 1.51 \\
\hline 207674_at & Fc fragment of IgA, receptor for & FCAR & 0.012 & 1.99 \\
\hline 211307_s_at & FC fragment of IgA, receptor for & FCAR & 0.012 & 1.72 \\
\hline 221345_at & free fatty acid receptor 2 & FFAR2 & 0.007 & 2.34 \\
\hline 209189_at & FBJ murine osteosarcoma viral oncogene homolog & FOS & 0.01 & 1.70 \\
\hline 213524_s_at & G0/G1switch 2 & Gos2 & 0.024 & 3.90 \\
\hline 207387_s_at & glycerol kinase & GK & 0.035 & 1.61 \\
\hline 208524_at & G protein-coupled receptor 15 & GPR15 & 0.024 & 1.66 \\
\hline 211555_s_at & guanylate cyclase 1 , soluble, beta 3 & GUCY1B3 & 0.011 & 1.59 \\
\hline 214455_at & histone cluster 1, H2bg & HIST1H2BG & 0.041 & 1.88 \\
\hline 1555464_at & interferon induced with helicase $C$ domain 1 & $|F| H \mid$ & 0.026 & 1.55 \\
\hline 211506_s_at & interleukin 8 & $1 / 28$ & 0.022 & 3.69 \\
\hline 220266_s_at & Kruppel-like factor 4 (gut) & KLF4 & 0.034 & 1.61 \\
\hline 208960_s_at & Kruppel-like factor 6 & KLF6 & 0.038 & 1.88 \\
\hline 217738_at & nicotinamide phosphoribosyltransferase & NAMPT & 0.027 & 1.73 \\
\hline 217739_s_at & nicotinamide phosphoribosyltransferase & NAMPT & 0.021 & 1.80 \\
\hline 243296_at & nicotinamide phosphoribosyltransferase & NAMPT & 0.008 & 2.00 \\
\hline 203574_at & nuclear factor, interleukin 3 regulated & NFIL3 & 0.008 & 1.55 \\
\hline 216015_s_at & NLR family, pyrin domain containing 3 & NLRP3 & 0.041 & 1.52 \\
\hline 205660_at & 2'-5'-oligoadenylate synthetase-like & OASL & 0.035 & 1.50 \\
\hline 224102_at & purinergic receptor P2Y, G-protein coupled, 12 & P2RY12 & 0.022 & 1.56 \\
\hline 201120_s_at & progesterone receptor membrane component 1 & PGRMC1 & 0.008 & 1.54 \\
\hline 210845_s_at & plasminogen activator, urokinase receptor & PLAUR & 0.004 & 1.60 \\
\hline 211924_s_at & plasminogen activator, urokinase receptor & PLAUR & 0.004 & 1.76 \\
\hline 204285_s_at & phorbol-12-myristate-13-acetate-induced protein 1 & PMAIP1 & 0.005 & 1.52 \\
\hline 202014_at & protein phosphatase 1 , regulatory (inhibitor) subunit $15 \mathrm{~A}$ & PPP1R15A & 0.012 & 1.96 \\
\hline 37028_at & protein phosphatase 1, regulatory (inhibitor) subunit 15A & PPP1R15A & 0.008 & 1.87 \\
\hline 1554997_a_at & $\begin{array}{l}\text { prostaglandin-endoperoxide synthase } 2 \text { (prostaglandin } \mathrm{G} / \mathrm{H} \text { synthase and } \\
\text { cyclooxygenase) }\end{array}$ & PTGS2 & 0.025 & 2.77 \\
\hline 200730_s_at & protein tyrosine phosphatase type IVA, member 1 & PTP4A1 & 0.03 & 1.62 \\
\hline 1569599_at & SAM domain, SH3 domain and nuclear localization signals 1 & SAMSN1 & 0.006 & 1.72 \\
\hline 222088_s_at & solute carrier family 2 (facilitated glucose transporter), member 14 & SLC2A14 & 0.033 & 1.56 \\
\hline 215223_s_at & superoxide dismutase 2, mitochondrial & SOD2 & 0.038 & 1.57 \\
\hline 205214_at & serine/threonine kinase $17 \mathrm{~b}$ & STK17B & 0.004 & 1.60 \\
\hline 210190_at & syntaxin 11 & STX11 & 0.003 & 1.65 \\
\hline 1552542_s_at & T-cell activation RhoGTPase activating protein & TAGAP & 0.004 & 1.66 \\
\hline 235086_at & thrombospondin 1 & THBS1 & 0.038 & 2.12 \\
\hline
\end{tabular}


Table 2 Differentially expressed probes/genes in the setting of peripheral arterial disease (Continued)

\begin{tabular}{|c|c|c|c|c|}
\hline 221060_s_at & toll-like receptor 4 & TLR4 & 0.025 & 1.82 \\
\hline 206116_s_at & tropomyosin 1 (alpha) & TPM1 & 0.013 & 1.58 \\
\hline 241133_at & T cell receptor beta constant 1 & TRBC1 & 0.048 & 1.91 \\
\hline $\begin{array}{l}\text { Downregulated Probe } \\
\text { ID }\end{array}$ & Gene name (HUGO) & Gene name & $P$-value & FCA \\
\hline 239661_at & AF4/FMR2 family, member 1 & AFF1 & 0.022 & 1.63 \\
\hline 220467_at & - & AL590452.1 & 0.043 & 1.56 \\
\hline 236921_at & - & AL592494.5 & 0.027 & 1.64 \\
\hline 238807_at & ankyrin repeat domain 46 & ANKRD46 & 0.038 & 1.53 \\
\hline 216198_at & activating transcription factor 7 interacting protein & ATFTIP & 0.026 & 1.50 \\
\hline 236307_at & BTB and CNC homology 1, basic leucine zipper transcription factor 2 & $\mathrm{BACH} 2$ & 0.039 & 2.11 \\
\hline 236796_at & BTB and CNC homology 1, basic leucine zipper transcription factor 2 & $\mathrm{BACH} 2$ & 0.015 & 1.70 \\
\hline 244172_at & B-cell linker & BLNK & 0.043 & 1.78 \\
\hline 227576_at & BMP2 inducible kinase-like & $B M P 2 K L$ & 0.048 & 1.83 \\
\hline 244425_at & chromosome 14 open reading frame 43 & C14orf43 & 0.03 & 1.65 \\
\hline 238635_at & chromosome 5 open reading frame 28 & C5orf28 & $\begin{array}{l}0.00 \mathrm{E} \\
+00\end{array}$ & 2.03 \\
\hline 232330_at & chromosome 7 open reading frame 44 & C7orf44 & 0.046 & 1.58 \\
\hline 239545_at & CAS1 domain containing 1 & CASD1 & 0.024 & 1.64 \\
\hline 1564164_at & DENN/MADD domain containing 1B & DENND1B & 0.048 & 1.53 \\
\hline 230653_at & DIS3 mitotic control homolog (S. cerevisiae)-like 2 & DIS3L2 & 0.039 & 1.77 \\
\hline 244876_at & early B-cell factor 1 & EBF1 & 0.034 & 1.50 \\
\hline 230983_at & family with sequence similarity 129 , member $C$ & FAM129C & 0.043 & 1.63 \\
\hline 1563674_at & Fc receptor-like 2 & FCRL2 & 0.041 & 1.68 \\
\hline 228623_at & FTX transcript, XIST regulator (non-protein coding) & FTX & 0.048 & 1.82 \\
\hline 1562289_at & G protein-coupled receptor 141 & GPR141 & 0.036 & 1.66 \\
\hline 206785_s_at & killer cell lectin-like receptor subfamily C, member 1 & KLRC1 & 0.035 & 1.69 \\
\hline 224559_at & metastasis associated lung adenocarcinoma transcript 1 (non-protein coding) & MALAT1 & 0.032 & 1.68 \\
\hline 243736_at & methyltransferase like 15 & METT5D1 & 0.034 & 1.59 \\
\hline 232478_at & MIR181A2 host gene (non-protein coding) & MIR181A2HG & 0.021 & 1.52 \\
\hline 228623_at & FTX transcript, XIST regulator (non-protein coding) & FTX & 0.048 & 1.82 \\
\hline 243310_at & - & - & 0.017 & 1.52 \\
\hline 239673_at & nuclear receptor subfamily 3 , group C, member 2 & NR3C2 & 0.037 & 1.94 \\
\hline 240128_at & 5'-nucleotidase, cytosolic III & NT5C3 & 0.03 & 1.57 \\
\hline 1559054_a_at & protein phosphatase 1, regulatory (inhibitor) subunit 7 & PPPIR7 & 0.004 & 1.60 \\
\hline 238875_at & RANBP2-like and GRIP domain containing 1 & RGPD1 & 0.026 & 1.50 \\
\hline 241838_at & - & $R P 1-167 A 14.2$ & 0.034 & 1.54 \\
\hline 242239_at & - & RP11-139J15.3 & 0.008 & 1.55 \\
\hline 228390_at & - & $\begin{array}{l}\text { RP11- } \\
\text { 659G9.3001 }\end{array}$ & 0.033 & 1.57 \\
\hline 213939_s_at & RUN and FYVE domain containing 3 & RUFY3 & 0.035 & 1.50 \\
\hline 244267_at & SATB homeobox 1 & SATB1 & 0.025 & 1.81 \\
\hline 236561_at & transforming growth factor, beta receptor 1 & TGFBR1 & 0.033 & 1.66 \\
\hline 236427_at & WW domain containing oxidoreductase & WWOX & 0.035 & 1.61 \\
\hline 1556543_at & zinc finger, CCHC domain containing 7 & ZCCHC7 & 0.041 & 1.68 \\
\hline 228157_at & zinc finger protein 207 & ZNF207 & 0.027 & 2.01 \\
\hline 236562_at & zinc finger protein 439 & ZNF439 & 0.015 & 1.51 \\
\hline 240155_x_at & zinc finger protein 479 & ZNF479 & 0.012 & 1.52 \\
\hline 1558486_at & zinc finger protein 493 & ZNF493 & 0.012 & 1.53 \\
\hline
\end{tabular}

FCA = Fold change absolute

- = HUGO Gene Nomenclature Committee (HGNC) assigned unique gene name is not available 


\section{Differentially regulated genes}

\section{$\downarrow$}

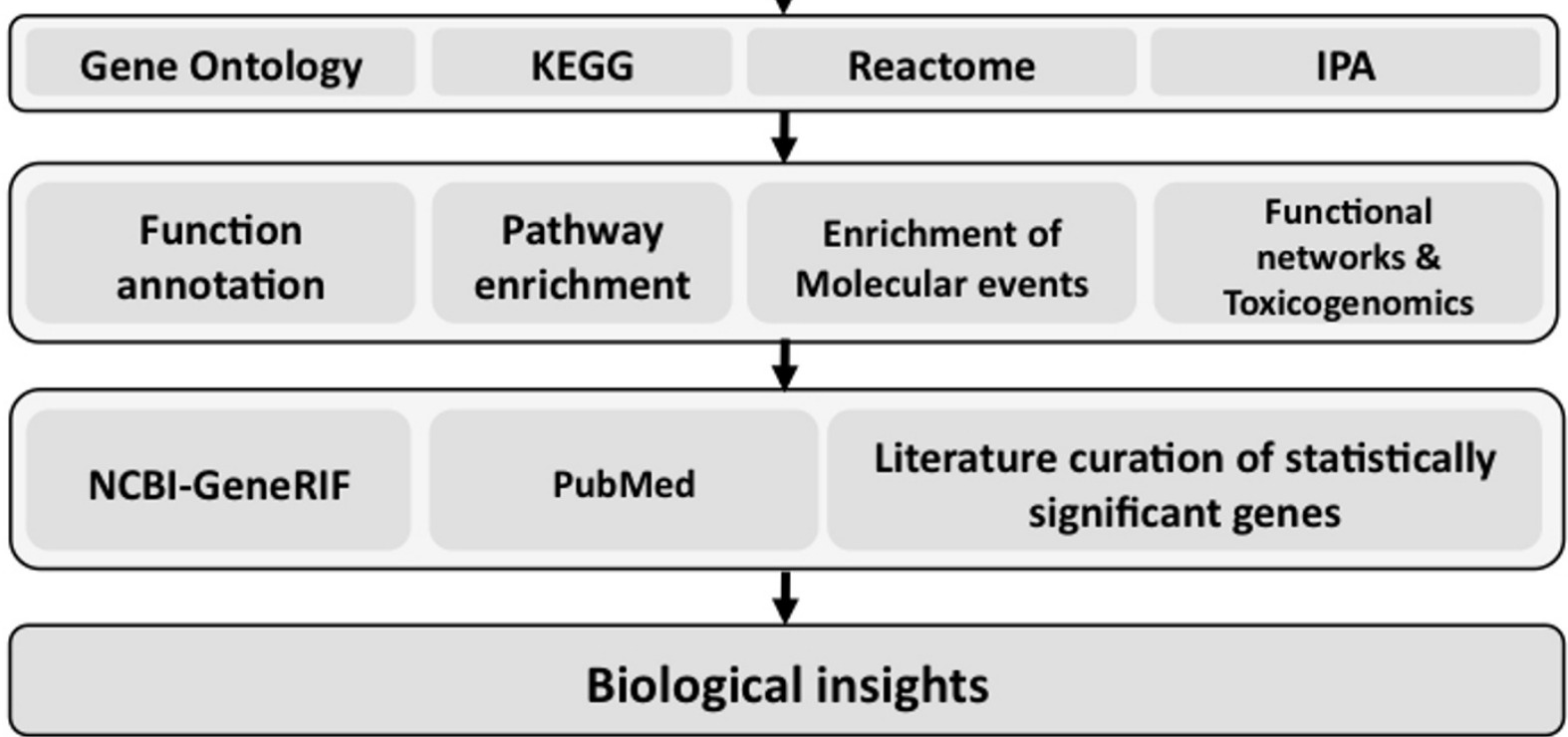

Figure 2 Bioinformatics pipeline used for the biological interpretation of differentially expressed genes

(inflammatory response; response to protein stimulus, response to organic substance, cytokine activity); immune response (defense response, regulation of response to external stimulus), cell death (induction of apoptosis by extracellular signals, regulation of cell proliferation, positive regulation of anti-apoptosis, regulation of apoptosis) and stress response (response to oxidative stress, response to reactive oxygen species, response to hyperoxia). Other important biological processes mediated by upregulated genes were regulation of peptidase activity, caspase activity and endopeptidase activity. A visual summary of GO identifiers associated

Table 3 Statistically significant GO terms derived from upregulated genes

\begin{tabular}{lc}
\hline Gene Ontology ID: Term & $\begin{array}{l}P \text { - } \\
\text { value }\end{array}$ \\
\hline $\begin{array}{l}\text { Biological process } \\
\text { See Additional file 1: Table S1 } \\
\text { Cellular component }\end{array}$ \\
\hline GO:0005886: plasma membrane & 0.043 \\
\hline Molecular function & 0.034 \\
\hline GO:0003690: double-stranded DNA binding & 0.040 \\
\hline GO:0004725: protein tyrosine phosphatase activity & 0.040 \\
\hline GO:0033549: MAP kinase phosphatase activity & 0.040 \\
\hline $\begin{array}{l}\text { GO:0017017: MAP kinase tyrosine/serine/threonine phosphatase } \\
\text { activity }\end{array}$ & \\
\hline
\end{tabular}

with upregulated genes (Figure 3) were created using REVIGO [32]. Molecular functions of the upregulated genes included phosphatase activity. GO terms associated with downregulated genes were enriched for various terms related to transcriptional regulation. These results indicate that the $\mathrm{PBMC}$, in the setting of $\mathrm{PAD}$, differentially express genes involved in inflammation,

Table 4 Statistically significant GO terms derived from downregulated genes

\begin{tabular}{ll}
\hline Gene Ontology ID: Term & $P$-value \\
\hline Molecular function & \\
\hline GO:0006355: regulation of transcription, DNA-dependent & 0.000 \\
\hline GO:0051252: regulation of RNA metabolic process & 0.000 \\
\hline GO:0045449: regulation of transcription & 0.000 \\
\hline GO:0006350: transcription & 0.004 \\
\hline GO:0045941: positive regulation of transcription & 0.042 \\
\hline GO:0010628: positive regulation of gene expression & 0.045 \\
\hline Biological process & \\
\hline GO:0003677: DNA binding & 0.001 \\
\hline GO:0030528: transcription regulator activity & 0.001 \\
\hline GO:0003700: transcription factor activity & 0.002 \\
\hline GO:0046914: transition metal ion binding & 0.040 \\
\hline GO:0008270: zinc ion binding & 0.043 \\
\hline GO:0046983: protein dimerization activity & 0.049 \\
\hline
\end{tabular}


Table 5 KEGG Pathway enrichment analysis results

\begin{tabular}{lll}
\hline KEGG ID & Pathway Name & P-value \\
\hline KEGG Pathways mediated by upregulated genes & \\
\hline path:05219 & Bladder cancer & 0.000 \\
\hline path:05144 & Malaria & 0.000 \\
\hline path:04115 & p53 signaling pathway & 0.000 \\
\hline path:05140 & Leishmaniasis & 0.001 \\
\hline path:05164 & Influenza A & 0.001 \\
\hline path:05323 & Rheumatoid arthritis & 0.001 \\
\hline path:04620 & Toll-like receptor signaling pathway & 0.001 \\
\hline path:05142 & Chagas disease (American trypanosomiasis) & 0.001 \\
\hline path:04145 & Phagosome & 0.005 \\
\hline path:05200 & Pathways in cancer & 0.005 \\
\hline path:04621 & NOD-like receptor signaling pathway & 0.007 \\
\hline path:04622 & RIG-l-like receptor signaling pathway & 0.010 \\
\hline path:04010 & MAPK signaling pathway & 0.021 \\
\hline path:05146 & Amoebiasis & 0.022 \\
\hline path:00533 & Glycosaminoglycan biosynthesis - keratan sulfate & 0.032 \\
\hline path:05162 & Measles & 0.034 \\
\hline path:05160 & Hepatitis C & 0.034 \\
\hline KEGG Pathways mediated by downregulated genes & \\
\hline path:04380 & Osteoclast differentiation & 0.016 \\
\hline path:00760 & Nicotinate and nicotinamide metabolism \\
\hline
\end{tabular}

immune response, apoptosis, molecular specific functions mediated by peptidase, caspase and stress response related pathways. Results of the GO annotation based enrichment analysis of upregulated and downregulated genes are summarized in Tables 3 and 4.

\section{KEGG pathways associated with differentially expressed genes}

SubPathwayMiner was used to assess the statistical significance of KEGG pathways associated with differentially expressed genes. Probes were mapped to genes identifiers and gene identifiers were used as the input in the statistical analysis. The enrichment analysis revealed that 17 pathways were associated with upregulated genes and two pathways were significant in downregulated genes $(P<$ 0.05 ) and multiple testing correction was performed using FDR. Analysis of KEGG pathway classes indicates that these pathways mediate cellular processing, signal transduction, immune system and infectious diseases. These analyses suggest that perturbations in multiple signaling and cellular mechanisms occur in PBMC in the setting of PAD. Significantly enriched pathways and corresponding P-values are listed in Table 5.

\section{Molecular events associated with PAD}

Compared to classical biological pathway databases, Reactome provides biological processes as a series of molecular
Table 6 Reactome molecular events enriched in upregulated genes

\begin{tabular}{ll}
\hline Reactome Pathway & $\begin{array}{l}\boldsymbol{P} \text { - } \\
\text { value }\end{array}$ \\
\hline Platelet Activation & 0.011 \\
\hline Formation of Platelet plug & 0.015 \\
\hline Exocytosis of platelet alpha granule contents & 0.016 \\
\hline Metabolism of water-soluble vitamins and cofactors & 0.017 \\
\hline Chemokine receptors bind chemokines & 0.021 \\
\hline Metabolism of vitamins and cofactors & 0.022 \\
\hline Liganded Gi-activating GPCR acts as a GEF for Gi & 0.023 \\
\hline The Ligand:GPCR:Gi complex dissociates & 0.023 \\
\hline Liganded Gi-activating GPCRs bind inactive heterotrimeric G- & 0.023 \\
\hline protein Gi & \\
\hline NFkB and MAP kinases activation mediated by TLR4 signaling & 0.025 \\
\hline repertoire & \\
\hline Hemostasis & 0.027 \\
\hline MyD88-independent cascade initiated on plasma membrane & 0.028 \\
\hline G alpha (i) signalling events & 0.029 \\
\hline Class A/1 (Rhodopsin-like receptors) & 0.030 \\
\hline Toll Like Receptor 10 (TLR10) Cascade & 0.033 \\
\hline Toll Like Receptor 5 (TLR5) Cascade & 0.033 \\
\hline MyD88 cascade initiated on plasma membrane & 0.033 \\
\hline MyD88:Mal cascade initiated on plasma membrane & 0.035 \\
\hline Toll Like Receptor TLR1:TLR2 Cascade & 0.035 \\
\hline Activated TLike Receptor TLR6:TLR2 Cascade & 0.035 \\
\hline Response to elevated platelet cytosolic Ca2+ & 0.035 \\
\hline & 0.040 \\
\hline
\end{tabular}

events and is thus a unique resource for functional interpretation of genes lists with a wide array of pathways, specific biological process and molecular events. We used the probe identifiers as the input for Reactome based enrichment analysis to find molecular events associated with differentially expressed genes using a hypergeometric test ( $P$ $<0.05)$. Pathway analysis using Reactome showed that upregulated genes were implicated in five platelet related pathways (platelet activation, formation of platelet plug, exocytosis of platelet alpha granule contents, platelet degranulation and response to elevated platelet cytosolic $\mathrm{Ca} 2+$ ). Two vitamin metabolism related events (Metabolism of water-soluble vitamins and cofactors, Metabolism of vitamins and cofactors) were also associated with upregulated genes (Table 6). Similar to KEGG pathway enrichment (Table 5), we also observed enrichment of several signal transduction events in the Reactome analysis. There was no significant enrichment of molecular events observed in the downregulated genes. 
Table 7 Biological networks derived using IPA network analysis

\begin{tabular}{ll}
\hline Top networks derived using upregulated genes & Score \\
\hline Associated functional network & 39 \\
\hline Cell Death, Renal Necrosis/Cell Death, Cancer & 24 \\
\hline Cardiovascular Disease, Hematological Disease, Infection Mechanism & 21 \\
\hline Inflammatory Response, Embryonic Development, Cell-To-Cell Signaling and Interaction & 2 \\
\hline Neurological Disease, RNA Post-Transcriptional Modification & 2 \\
\hline Cardiovascular Disease, Genetic Disorder, Cellular Function and Maintenance & 13 \\
\hline Top networks derived using downregulated genes & 3 \\
\hline Cellular Development, Cellular Assembly and Organization, Cell Cycle & 3 \\
\hline Genetic Disorder, Ophthalmic Disease, Nervous System Development and Function & 2 \\
\hline Cellular Assembly and Organization, Cell Morphology, Cellular Function and Maintenance
\end{tabular}

\section{Functional network inferred using IPA}

We used IPA to understand the functionally significant biological networks and toxicogenomics associations mediated by the differentially expressed genes in the setting of PAD. IPA analysis was performed using probe identifiers as the input; the reference dataset was defined as 'Human Genome U133 Plus 2'; direct interactions only were considered for the analysis. Biological network (Table 7) and toxicity functions (Table 8) derived from IPA are provided and illustrated in Figure 4 (a) (merged view of networks derived from upregulated genes) and Figure 4 (b) (merged view of networks derived from downregulated genes). Different shapes of nodes indicate "Family" of a given gene assigned using IPA annotations. Color of node indicates the presence (grey) or absence (white) of a given gene in the study. Nodes that are not represented in the study (white nodes) were retained in the network for a context dependent view of the functional interactome. Edges shared between six different functional networks derived from upregulated genes were highlighted (Figure 4 (a)). Downregulated genes do not share any common nodes between the derived functional networks (Figure 4 (b)). It should be noted that upregulated genes interacted with several core genes (interactions are highlighted with edges colored in orange) that are present in multiple networks, where

Table 8 Toxicity functions derived from IPA network analysis

\begin{tabular}{ll}
\hline \multicolumn{2}{l}{ Top Tox lists derived from upregulated genes } \\
\hline Name & P-value \\
\hline Renal Necrosis/Cell Death & 0.000 \\
\hline Liver Necrosis/Cell Death & 0.000 \\
\hline Increases Renal Proliferation & 0.001 \\
\hline Oxidative Stress & 0.001 \\
\hline Cardiac Necrosis/Cell Death & 0.002 \\
\hline
\end{tabular}

as the downregulated genes did not interact with the core genes. These results suggest that that upregulated genes identified in our study may influence multiple functional networks via interaction with the core genes. Further studies are required to understand role of these genes in the pathophysiology of PAD.

\section{Biocuration of differentially expressed genes}

We performed in-depth biocuration of differentially regulated genes using a combination of resources. For a given differentially expressed gene we consulted General annotation under the Comments section in UniProt, RefSeq summary, GeneRIF and publications linked under "Related Articles" in PubMed section of "Bibliography" in individual Gene pages. Biocuration was performed to manually extract the role of differentially expressed pertaining to vascular diseases including PAD from previous literature reports. Curated data with functional context and role of genes in vascular diseases and associated references are presented in Additional file 1: Table S2. This approach further helped to extract functionally relevant information not captured by ontologies or annotations in automated analytical frameworks used in enrichment tools.

\section{Discussion}

We report for the first time gene expression analysis of PBMC to identify genes differentially expressed in patients with PAD. Enrichment analysis of GO terms and pathways associated with these genes provide insights into several known and novel molecular mechanisms related to PAD. The two genes with highest fold change absolute (FCA) were: G0/G1switch 2 (GOS2; FCA: 3.90 ; $\uparrow)$ BTB and CNC homology 1, basic leucine zipper transcription factor $2(B A C H 2$; FCA: $2.10 ; \downarrow)$. GOS2 is a novel target of peroxisome-proliferator-activated receptor $(P P A R)$ involved in adipocyte differentiation [33,34]. $B A C H 2$ is a transcriptional regulator that 


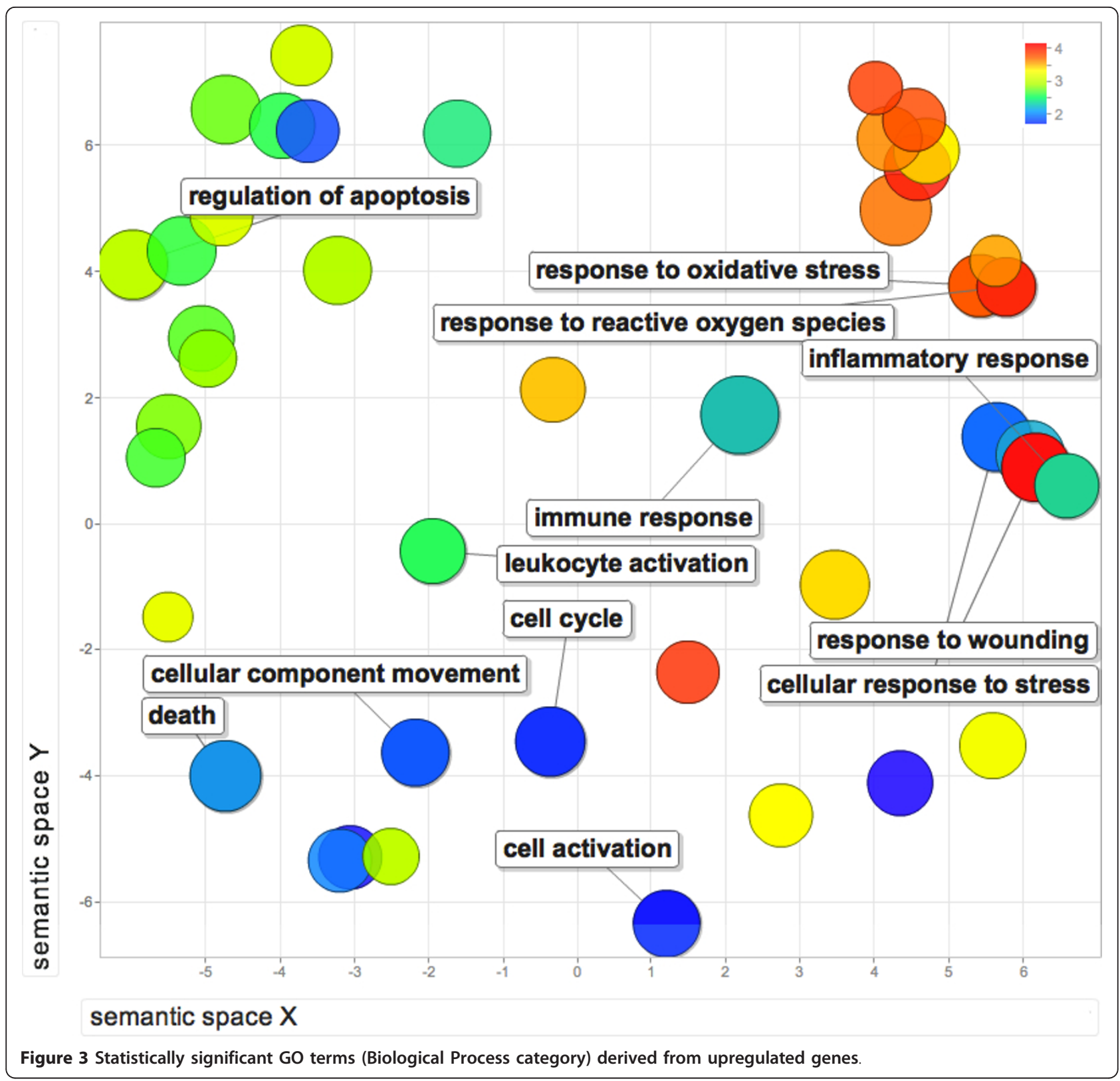

acts as repressor or activator through the nuclear factor (erythroid-derived 2), $45 \mathrm{kDa}$ (NFE2) binding sites $[35,36]$. Differentially regulated genes, summarized in Table 2 are ideal candidates for further, down-stream functional studies.

Biological relevance of differentially expressed genes in the setting of PAD

Knowledge-based statistical analysis of differentially expressed genes provided molecular clues for the interpretation of the function or pathways associated with these genes. We used the statistically significant genes, GO terms and pathways as leads to perform in-depth literature curation. The detailed literature curation indicated that the genes identified in this study are relevant to various aspects of vascular biology and pathophysiology of PAD.

Several of the differentially regulated genes are involved in vascular pathophysiology; for example: DNAJB6 [37] and DUSP1 (atherosclerosis) [38], NAMPT (vascular inflammation) [39,40], FCAR (myocardial infarction) [41], IL8 (vascular remodelling) [42], FFAR2 (lipid metabolism) [43] and SOD2 (idiopathic cardiomyopathy (IDC)) [44]. Notably, several genes known to be associated with vascular disease were upregulated as discussed below. 


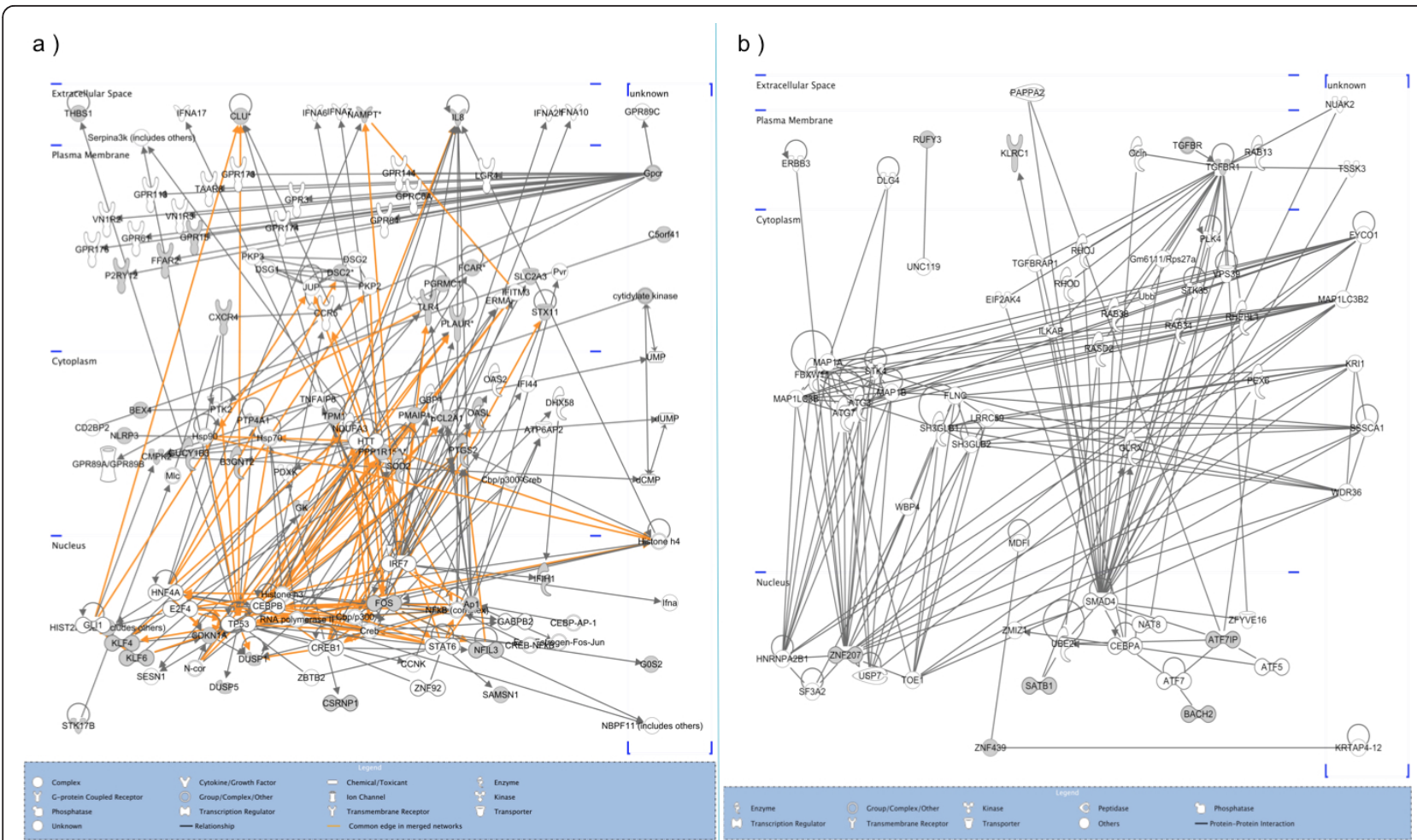

Figure 4 Functional networks inferred using IPA. a) Merged view of functional network derived from upregulated genes using IPA (Network 1: Cell Death, Renal Necrosis/Cell Death, Cancer; Network 2: Cardiovascular Disease, Hematological Disease, Infection Mechanism; Network 3: Inflammatory Response, Embryonic Development, Cell-To-Cell Signaling and Interaction Network 4: Neurological Disease, RNA Post-Transcriptional Modification; Network 5: Cardiovascular Disease, Genetic Disorder, Cellular Function and Maintenance; Network 6: Drug Metabolism, Nucleic Acid Metabolism, Small Molecular Biochemistry). b) Functional networks derived from downregulated genes using IPA (Network 1: Cellular Development, Cellular Assembly and Organization, Cell Cycle; Network 2: Genetic Disorder, Ophthalmic Disease, Nervous System Development and Function; Network 3: Embryonic Development, Gene Expression, Protein Trafficking Network 4: Cellular Assembly and Organization, Cell Morphology, Cellular Function and Maintenance).

Phosphatases are known to be associated with peripheral arterial disease [45-47]. We noted that four phosphatase genes PTP4A1, DUSP1, DUSP5, PPP1R15A are significantly upregulated in the PBMC of patients with PAD. Apoptosis, along with inflammation and immune response, is a key feature of vascular diseases [5,48-52]. Our study indicates genes implicated in inflammation, immune response (FCAR, FFAR2, IL8, CFLAR, DUSP1, NAMPT) and cell death (GOS2, KLF6, PTP4A1, CFLAR) are differentially expressed in PBMC of PAD patients. Oxidative-stress response is known to be associated with PAD [53-56]; we noted that several "oxidative-stress response" related functions were enriched in GO term analysis and IPA analysis. Altered metabolism of vitamins and vitamin D deficiency has been reported to be associated with PAD [57,58]. Enrichment analysis using molecular event annotations (Table 6) and GO term analysis (Table 3 ) indicated that vitamin metabolism related pathways are upregulated in the setting of PAD. Platelet aggregation is strongly linked to PAD [1,6,59-62] and Reactome based pathway analysis indicated that several platelet-related molecular events were associated with upregulated genes such as PLAUR (Table 6).

Apart from these known genes, we noted several genes not previously associated with PAD to be differentially expressed. Upregulation of validated gene STX11 suggests a putative role for genes associated with vesicle trafficking in the pathophysiology of PAD. Upregulation of FFAR2 suggests altered free fatty acid metabolism in the setting of PAD. Further investigation of differentially regulated transcription factors (for example: C5orf41, KLF6, BACH2), and their downstream target genes may provide additional insights into the molecular basis of PAD.

\section{Comparison with previous studies}

Several of the differentially expressed genes identified in the current study were previously reported to be associated with various vascular biology processes. For example thrombospondin-1 (THBS1) [63-65], phosphatases (DUSP1) [45], plasminogen activator, urokinase receptor (PLAUR) [60], cadherins (DSC2) [66,67] and 
zinc finger proteins (ZNF207) [68-71] have been implicated in vascular homeostasis and pathophysiology of PAD. Prior microarray studies of PAD have also demonstrated a pattern of activation of genes involved in immune and inflammatory response [72]. Our study is designed to identify perturbed genes in PBMCs in the setting of PAD. Fu et al., [72] performed microarray analysis of atherosclerotic lesions of femoral arteries, and found that immune and inflammatory pathways were enriched in PAD cases. We replicated the following genes from $\mathrm{Fu}$ et. al's analysis: CDKN1A, CXCR4, KLF4, PLAUR, SAMSN1, SOD2 and THBS1. Wingrove et al., [10] performed whole-genome microarray analysis on PBMCs of 27 cases with angiographic coronary artery stenosis and 14 controls and identified 526 genes with $>1.3$-fold differential expression $(P<0.05)$ between cases and controls. Real time PCR in two independent cohorts (149 cases and 53 controls) for 106 genes (the 50 most significant genes and 56 additional candidate genes) confirmed that 11 genes were significantly differentially expressed between cases and controls. The differentially expressed genes that we identified in the setting of PAD did not overlap with genes found by Wingrove et al., [10] but we validated several genes differentially expressed in intermediate lesions and advanced lesions derived from femoral artery samples analyzed by Fu et al [72]. Evans et al., [73] performed microarray analysis of leg arteries and identified genes involved in inflammation and lipid uptake pathways in the setting of PAD with diabetes. Similar to observations by Evans et al., [73] we also noted that inflammation and related GO terms like immune response, apoptosis, response to stress, cell proliferation and circulation were enriched in the GO annotations of upregulated genes. Differences in methodology, sources of mRNA and the fact that PAD and CAD are distinct phenotypic manifestations of atherosclerosis may account for the varying results.

\section{Integrated approach for functional interpretation}

We integrated four different annotation resources for functional interpretation of differentially expressed genes (Figure 2). GO annotations provided a comprehensive view of the function and processes, pathway enrichment using KEGG provided disease association of differentially expressed genes, Reactome was useful in understanding molecular events associated with genes and IPA facilitated understanding of functional networks (group of genes that share common functions) and toxicity functions. Although annotations shared several common entities, each tool provided a unique perspective of the differentially regulated genes in the setting of PAD. Further, we also employed in- depth biocuration strategies to understand the functional and pathological relevance of differentially expressed genes in the setting of vascular disease. Our integrated bioinformatics approach coupled with biocuration provided insights into the functional repertoire of differentially expressed genes.

\section{Strength and Limitations}

A strength of this report is the application of integrative bioinformatics pipeline employed to understand the functional similarities, biological pathways, molecular events and functional networks, related to differentially expressed genes. In addition we performed indepth literature curation to understand functional relevance of these genes. Further we validated a novel differentially regulated gene STX11 using qRT-PCR. Complete characterization of the genes identified in this study in the context of their relevance to PAD will require further validation and functional studies. We derived the RNA from PBMC, which may have perturbations in the cellular level due to fluctuation in cluster of differentiation 4 (CD4) count within cases and controls. Patients in our study were ascertained based on $\mathrm{ABI}$ (ABI $\leq 0.9$ for cases and ABI $>1.0$ for controls), additional clinical biomarkers such as $\mathrm{T}$ lymphocytes (T cells) and Natural killer cells (NK cells) or CD4 counts were not available.

\section{Conclusion}

Gene expression profiling of circulating PBMC provided a global overview of differential gene expression in PAD; where 87 differentially expressed genes (47 upregulated genes and 39 downregulated genes). Integrated bioinformatics analysis of differentially regulated genes using multiple annotation tools indicated that the differentially regulated genes influence immune response, inflammation, apoptosis, various signalling pathways and various functions pertaining to vascular biology. Our whole-genome expression and bioinformatics analysis suggests that microarray based expression profiling may be useful for characterizing biomarkers for PAD. Understanding and validating groups of differentially expressed genes in the setting of PAD using PBMC can improve our understanding of the key pathophysiological mechanisms in the aetiology of PAD. Further clinical and functional studies may provide additional insights into role of the differentially expressed genes in the pathophysiology of PAD.

\section{Availability}

Gene expression data discussed in this study was submitted to Gene Expression Omnibus (GEO) database, and can be accessed via GEO accession ID GSE27034. 


\section{Additional material}

Additional file 1: Table S1 Statistically significant GO terms (biological process category)Supplementary. Table S2 Functional context and biological relevance of differentially expressed genes in vascular diseases [38-40,42,43,46,68,74-146].

\section{Acknowledgements}

This study was supported by a Marriot Award for Individualized Medicine. We acknowledge Angie Dalenberg, Advanced Genomic Technology Center and Microarray Shared Resource at Mayo Clinic for technical assistance.

\section{Authors' contributions}

RM performed the experiments and contributed to the analysis. KS performed the analysis. AD contributed to the experiments. KD contributed to the analysis. KS and IJK wrote the manuscript with contributions from other authors. IJK conceived the study and provided critical input. All authors read and approved the final manuscript.

\section{Competing interests}

The authors declare that they have no competing interests.

Received: 21 September 2011 Accepted: 12 March 2012

Published: 12 March 2012

\section{References}

1. Hirsch AT, Criqui MH, Treat-Jacobson D, Regensteiner JG, Creager MA, Olin JW, Krook SH, Hunninghake DB, Comerota AJ, Walsh ME, et al: Peripheral arterial disease detection, awareness, and treatment in primary care. JAMA 2001, 286(11):1317-1324.

2. Allison MA, Ho E, Denenberg JO, Langer RD, Newman AB, Fabsitz RR, Criqui MH: Ethnic-specific prevalence of peripheral arterial disease in the United States. Am J Prev Med 2007, 32(4):328-333.

3. Roger VL, Go AS, Lloyd-Jones DM, Adams RJ, Berry JD, Brown TM, Carnethon MR, Dai S, de Simone G, Ford ES, et al: Heart disease and stroke statistics-2011 update: a report from the American Heart Association. Circulation 2011, 123(4):e18-e209.

4. Ouriel K: Peripheral arterial disease. Lancet 2001, 358(9289):1257-1264

5. Hansson GK: Inflammation, atherosclerosis, and coronary artery disease. N Engl J Med 2005, 352(16):1685-1695.

6. Mohler ER: Peripheral arterial disease: identification and implications. Arch Intern Med 2003, 163(19):2306-2314.

7. Whitney AR, Diehn M, Popper SJ, Alizadeh AA, Boldrick JC, Relman DA, Brown PO: Individuality and variation in gene expression patterns in human blood. Proc Natl Acad Sci USA 2003, 100(4):1896-1901.

8. Eady JJ, Wortley GM, Wormstone YM, Hughes JC, Astley SB, Foxall RJ, Doleman JF, Elliott RM: Variation in gene expression profiles of peripheral blood mononuclear cells from healthy volunteers. Physiol Genomics 2005, 22(3):402-411.

9. Timofeeva AV, Goryunova LE, Khaspekov GL, Kovalevskii DA, Scamrov AV, Bulkina OS, Karpov YA, Talitskii KA, Buza W, Britareva W, et al: Altered gene expression pattern in peripheral blood leukocytes from patients with arterial hypertension. Ann N Y Acad Sci 2006, 1091:319-335.

10. Wingrove JA, Daniels SE, Sehnert AJ, Tingley W, Elashoff MR, Rosenbery S, Buellesfeld L, Grube E, Newby LK, Ginsburg GS, et al: Correlation of peripheral blood gene expression with the extent of coronary artery stenosis. Circ Cardiovasc Genet 2008, 1:31-38.

11. Rosenberg S, Elashoff MR, Beineke P, Daniels SE, Wingrove JA, Tingley WG, Sager PT, Sehnert AJ, Yau M, Kraus WE, et al: Multicenter validation of the diagnostic accuracy of a blood-based gene expression test for assessing obstructive coronary artery disease in nondiabetic patients. Annals of internal medicine 2005, 153(7):425-434.

12. Aziz H, Zaas A, Ginsburg GS: Peripheral blood gene expression profiling for cardiovascular disease assessment. Genomics Med 2007, 1(3-4):105-112.

13. Stamova B, Xu H, Jickling G, Bushnell C, Tian Y, Ander BP, Zhan X, Liu D, Turner R, Adamczyk $P$, et al: Gene expression profiling of blood for the prediction of ischemic stroke. Stroke 2010, 41(10):2171-2177.
14. Patino WD, Mian OY, Kang JG, Matoba S, Bartlett LD, Holbrook B, Trout HH: Kozloff L, Hwang PM: Circulating transcriptome reveals markers of atherosclerosis. Proc Natl Acad Sci USA 2005, 102(9):3423-3428.

15. Waehre T, Yndestad A, Smith C, Haug T, Tunheim SH, Gullestad L, Froland SS, Semb AG, Aukrust P, Damas JK: Increased expression of interleukin-1 in coronary artery disease with downregulatory effects of HMG-CoA reductase inhibitors. Circulation 2004, 109(16):1966-1972.

16. Meier P, Antonov J, Zbinden R, Kuhn A, Zbinden S, Gloekler S, Delorenzi M, Jaggi $R$, Seiler C: Non-invasive gene-expression-based detection of welldeveloped collateral function in individuals with and without coronary artery disease. Heart (British Cardiac Society) 2009, 95(11):900-908.

17. Kullo IJ, Bailey KR, Kardia SL, Mosley TH Jr, Boerwinkle E, Turner ST: Ethnic differences in peripheral arterial disease in the NHLBI Genetic Epidemiology Network of Arteriopathy (GENOA) study. Vasc Med 2003, 8(4):237-242.

18. Bielecki M, Kowal K, Lapinska A, Chwiecko J, Skowronski J, Sierakowski S, Chyczewski L, Kowal-Bielecka O: Diminished production of TWEAK by the peripheral blood mononuclear cells is associated with vascular involvement in patients with systemic sclerosis. Folia Histochem Cytobiol 2009, 47(3):465-469.

19. Irizarry RA, Hobbs B, Collin F, Beazer-Barclay YD, Antonellis KJ, Scherf U, Speed TP: Exploration, normalization, and summaries of high density oligonucleotide array probe level data. Biostatistics (Oxford, England) 2003, 4(2):249-264.

20. Saeed Al, Sharov V, White J, Li J, Liang W, Bhagabati N, Braisted J, Klapa M, Currier T, Thiagarajan M, et al: TM4: a free, open-source system for microarray data management and analysis. Biotechniques 2003, 34(2):374-378.

21. Wu C, Orozco C, Boyer J, Leglise M, Goodale J, Batalov S, Hodge CL, Haase J, Janes J, Huss JW, et al: BioGPS: an extensible and customizable portal for querying and organizing gene annotation resources. Genome Biol 2009, 10(11):R130.

22. da Huang W, Sherman BT, Lempicki RA: Bioinformatics enrichment tools: paths toward the comprehensive functional analysis of large gene lists. Nucleic Acids Res 2009, 37(1):1-13.

23. da Huang W, Sherman BT, Lempicki RA: Systematic and integrative analysis of large gene lists using DAVID bioinformatics resources. Nat Protoc 2009, 4(1):44-57.

24. Croft D, O'Kelly G, Wu G, Haw R, Gillespie M, Matthews L, Caudy M, Garapati P, Gopinath G, Jassal B, et al: Reactome: a database of reactions, pathways and biological processes. Nucleic Acids Res 2011, , 39 Database: D691-D697.

25. Kanehisa M, Goto S, Furumichi M, Tanabe M, Hirakawa M: KEGG for representation and analysis of molecular networks involving diseases and drugs. Nucleic Acids Res 2010, , 38 Database: D355-D360.

26. Chen R, Li L, Butte AJ: AlLUN: reannotating gene expression data automatically. Nat Methods 2007, 4(11):879.

27. Smedley D, Haider S, Ballester B, Holland R, London D, Thorisson G, Kasprzyk A: BioMart-biological queries made easy. BMC Genomics 2009, 10:22

28. Risueno A, Fontanillo C, Dinger ME, De Las Rivas J: GATExplorer: genomic and transcriptomic explorer; mapping expression probes to gene loci, transcripts, exons and ncRNAs. BMC Bioinformatics 2010, 11:221.

29. Rhead B, Karolchik D, Kuhn RM, Hinrichs AS, Zweig AS, Fujita PA, Diekhans M, Smith KE, Rosenbloom KR, Raney BJ, et al: The UCSC Genome Browser database: update 2010. Nucleic Acids Res 2010, , 38 Database: D613-D619.

30. Fernandez-Suarez $X M$, Schuster MK: Using the ensembl genome server to browse genomic sequence data. Curr Protoc Bioinformatics 2010, Chapter 1, Unit1 15.

31. Dennis G Jr, Sherman BT, Hosack DA, Yang J, Gao W, Lane HC, Lempicki RA: DAVID: Database for Annotation, Visualization, and Integrated Discovery. Genome Biol 2003, 4(5):P3.

32. Supek F, Bosnjak M, Skunca N, Smuc T: REVIGO summarizes and visualizes long lists of gene ontology terms. PLoS One 2011, 6(7):e21800.

33. Zandbergen $F$, Mandard S, Escher P, Tan NS, Patsouris D, Jatkoe T, RojasCaro S, Madore S, Wahli W, Tafuri S, et al: The G0/G1 switch gene 2 is a novel PPAR target gene. Biochem J 2005, 392(Pt 2):313-324.

34. Russell L, Forsdyke DR: A human putative lymphocyte G0/G1 switch gene containing a $\mathrm{CpG}$-rich island encodes a small basic protein with the potential to be phosphorylated. DNA Cell Biol 1991, 10(8):581-591. 
35. Oyake T, Itoh K, Motohashi H, Hayashi N, Hoshino H, Nishizawa M, Yamamoto $M$, lgarashi $\mathrm{K}$ : Bach proteins belong to a novel family of BTBbasic leucine zipper transcription factors that interact with MafK and regulate transcription through the NF-E2 site. Mol Cell Biol 1996, 16(11):6083-6095.

36. Vieira SA, Deininger MW, Sorour A, Sinclair P, Foroni L, Goldman JM, Melo JV: Transcription factor $\mathrm{BACH} 2$ is transcriptionally regulated by the BCR/ABL oncogene. Genes Chromosomes Cancer 2001, 32(4):353-363.

37. Civelek M, Manduchi E, Riley RJ, Stoeckert CJ Jr, Davies PF: Chronic endoplasmic reticulum stress activates unfolded protein response in arterial endothelium in regions of susceptibility to atherosclerosis. Circ Res 2009, 105(5):453-461.

38. Gargalovic PS, Imura M, Zhang B, Gharavi NM, Clark MJ, Pagnon J, Yang WP, He A, Truong A, Patel S, et al: Identification of inflammatory gene modules based on variations of human endothelial cell responses to oxidized lipids. Proc Natl Acad Sci USA 2006, 103(34):12741-12746.

39. Laudes M, Oberhauser F, Schulte DM, Freude S, Bilkovski R, Mauer J, Rappl G, Abken H, Hahn M, Schulz O, et al: Visfatin/PBEF/Nampt and resistin expressions in circulating blood monocytes are differentially related to obesity and type 2 diabetes in humans. Horm Metab Res 2010, 42(4):268-273

40. Kadoglou NP, Sailer N, Moumtzouoglou A, Kapelouzou A, Tsanikidis H, Vitta I, Karkos C, Karayannacos PE, Gerasimidis T, Liapis CD: Visfatin (nampt) and ghrelin as novel markers of carotid atherosclerosis in patients with type 2 diabetes. Exp Clin Endocrinol Diabetes 2010, 118(2):75-80.

41. lakoubova OA, Tong CH, Chokkalingam AP, Rowland CM, Kirchgessner TG, Louie JZ, Ploughman LM, Sabatine MS, Campos H, Catanese JJ, et al: Asp92Asn polymorphism in the myeloid IgA Fc receptor is associated with myocardial infarction in two disparate populations: CARE and WOSCOPS. Arterioscler Thromb Vasc Biol 2006, 26(12):2763-2768.

42. Li A, Dubey S, Varney ML, Dave BJ, Singh RK: IL-8 directly enhanced endothelial cell survival, proliferation, and matrix metalloproteinases production and regulated angiogenesis. J Immunol 2003, 170(6):3369-3376.

43. Lee T, Schwandner R, Swaminath G, Weiszmann J, Cardozo M, Greenberg J, Jaeckel $P$, Ge H, Wang $Y$, Jiao $X$, et al: Identification and functional characterization of allosteric agonists for the $G$ protein-coupled receptor FFA2. Mol Pharmacol 2008, 74(6):1599-1609.

44. Faraci FM, Didion SP: Vascular protection: superoxide dismutase isoforms in the vessel wall. Arterioscler Thromb Vasc Biol 2004, 24(8):1367-1373.

45. Carr AN, Davis MG, Eby-Wilkens E, Howard BW, Towne BA, Dufresne TE, Peters KG: Tyrosine phosphatase inhibition augments collateral blood flow in a rat model of peripheral vascular disease. Am J Physiol Heart Circ Physiol 2004, 287(1):H268-H276.

46. Zakkar M, Chaudhury H, Sandvik G, Enesa K, le Luong A, Cuhlmann S, Mason JC, Krams R, Clark AR, Haskard DO, et al: Increased endothelial mitogen-activated protein kinase phosphatase-1 expression suppresses proinflammatory activation at sites that are resistant to atherosclerosis. Circ Res 2008, 103(7):726-732.

47. Cheung BM, Ong KL, Wong LY: Elevated serum alkaline phosphatase and peripheral arterial disease in the United States National Health and Nutrition Examination Survey 1999-2004. Int J Cardiol 2009, 135(2):156-161.

48. Bennett MR: Apoptosis in vascular disease. Transpl Immunol 1997, 5(3):184-188.

49. Freyssinet JM, Toti F, Hugel B, Gidon-Jeangirard C, Kunzelmann C, Martinez MC, Meyer D: Apoptosis in vascular disease. Thromb Haemost 1999, 82(2):727-735.

50. Mercer J, Mahmoudi M, Bennett M: DNA damage, p53, apoptosis and vascular disease. Mutat Res 2007, 621(1-2):75-86.

51. Kockx MM, Knaapen MW: The role of apoptosis in vascular disease. J Pathol 2000, 190(3):267-280.

52. Sykes TC, Morris AG, Bradbury AW, Mosquera D: Apoptosis in vascular disease. Eur J Vasc Endovasc Surg 2001, 22(5):389-395.

53. Madamanchi NR, Vendrov A, Runge MS: Oxidative stress and vascular disease. Arterioscler Thromb Vasc Biol 2005, 25(1):29-38.

54. Forstermann $\mathrm{U}$ : Oxidative stress in vascular disease: causes, defense mechanisms and potential therapies. Nat Clin Pract Cardiovasc Med 2008, 5(6):338-349.
55. Belch JJ, Mackay IR, Hill A, Jennings P, McCollum P: Oxidative stress is present in atherosclerotic peripheral arterial disease and further increased by diabetes mellitus. Int Angiol 1995, 14(4):385-388.

56. Loffredo L, Marcoccia A, Pignatelli P, Andreozzi P, Borgia MC, Cangemi R, Chiarotti F, Violi F: Oxidative-stress-mediated arterial dysfunction in patients with peripheral arterial disease. Eur Heart J 2007, 28(5):608-612.

57. Fahrleitner A, Dobnig H, Obernosterer A, Pilger E, Leb G, Weber K, Kudlacek S, Obermayer-Pietsch BM: Vitamin D deficiency and secondary hyperparathyroidism are common complications in patients with peripheral arterial disease. J Gen Intern Med 2002, 17(9):663-669.

58. Gaddipati VC, Kuriacose R, Copeland R, Bailey BA, Peiris AN: Vitamin D deficiency: an increasing concern in peripheral arterial disease. $J$ Am Med Dir Assoc 2010, 11(5):308-311.

59. Karnicki K, Karnicki K, Miller RS, Owen WG: The impact of peripheral arterial disease on circulating platelets. Thromb Res 2004, 113(2):137-145.

60. Robless PA, Okonko D, Lintott P, Mansfield AO, Mikhailidis DP, Stansby GP: Increased platelet aggregation and activation in peripheral arterial disease. Eur J Vasc Endovasc Surg 2003, 25(1):16-22.

61. Cassar K, Bachoo P, Brittenden J: The role of platelets in peripheral vascular disease. Eur J Vasc Endovasc Surg 2003, 25(1):6-15.

62. Huo Y, Ley KF: Role of platelets in the development of atherosclerosis. Trends Cardiovasc Med 2004, 14(1):18-22.

63. Maier KG, Han X, Sadowitz B, Gentile KL, Middleton FA, Gahtan V: Thrombospondin-1: a proatherosclerotic protein augmented by hyperglycemia. J Vasc Surg 2010, 51(5):1238-1247.

64. Ochoa CD, Fouty BW, Hales CA: Thrombospondin-1, endothelium and systemic vascular tone. Future Cardiol 2011, 7(2):169-172.

65. Smadja DM, d'Audigier C, Bieche I, Evrard S, Mauge L, Dias JV, Labreuche J, Laurendeau I, Marsac B, Dizier B, et al: Thrombospondin-1 is a plasmatic marker of peripheral arterial disease that modulates endothelial progenitor cell angiogenic properties. Arterioscler Thromb Vasc Biol 2011, 31(3):551-559.

66. Jang $Y$, Lincoff AM, Plow EF, Topol EJ: Cell adhesion molecules in coronary artery disease. J Am Coll Cardiol 1994, 24(7):1591-1601.

67. George SJ, Dwivedi A: MMPs, cadherins, and cell proliferation. Trends Cardiovasc Med 2004, 14(3):100-105.

68. Pahl PM, Hodges YK, Meltesen L, Perryman MB, Horwitz KB, Horwitz LD: ZNF207, a ubiquitously expressed zinc finger gene on chromosome 6p21.3. Genomics 1998, 53(3):410-412.

69. Wagner $\mathrm{S}$, Hess MA, Ormonde-Hanson P, Malandro J, Hu H, Chen M, Kehrer R, Frodsham M, Schumacher C, Beluch M, et al: A broad role for the zinc finger protein ZNF202 in human lipid metabolism. J Biol Chem 2000, 275(21):15685-15690.

70. Yu J, Lei L, Liang Y, Hinh L, Hickey RP, Huang Y, Liu D, Yeh JL, Rebar E, Case $C$, et al: An engineered VEGF-activating zinc finger protein transcription factor improves blood flow and limb salvage in advancedage mice. FASEB J 2006, 20(3):479-481.

71. Quintal SM, dePaula QA, Farrell NP: Zinc finger proteins as templates for metal ion exchange and ligand reactivity. Chemical and biological consequences. Metallomics 2011, 3(2):121-139.

72. Fu S, Zhao H, Shi J, Abzhanov A, Crawford K, Ohno-Machado L, Zhou J, Du Y, Kuo WP, Zhang J, et al: Peripheral arterial occlusive disease: global gene expression analyses suggest a major role for immune and inflammatory responses. BMC Genomics 2008, 9:369.

73. Evans DC, Sileshi B, Zakaria AM, Giangiacomo D, Manson RJ, Lawson JH: Genomic modeling of atherosclerosis in peripheral arterial disease and its variant phenotype in patients with diabetes. Vascular 2008, 16(4):225-235

74. Seko A, Yamashita K: Activation of beta1,3-Nacetylglucosaminyltransferase-2 (beta3Gn-T2) by beta3Gn-T8. Possible involvement of beta3Gn-T8 in increasing poly-N-acetyllactosamine chains in differentiated HL-60 cells. J Biol Chem 2008, 283(48):33094-33100.

75. Karsan A, Yee E, Kaushansky K, Harlan JM: Cloning of human Bcl-2 homologue: inflammatory cytokines induce human A1 in cultured endothelial cells. Blood 1996, 87(8):3089-3096.

76. Alvarez E, Zhou W, Witta SE, Freed CR: Characterization of the Bex gene family in humans, mice, and rats. Gene 2005, 357(1):18-28. 
77. Pfeufer A, van Noord C, Marciante KD, Arking DE, Larson MG, Smith AV, Tarasov KV, Muller M, Sotoodehnia N, Sinner MF, et al: Genome-wide association study of PR interval. Nat Genet 2010, 42(2):153-159.

78. Audas TE, Li Y, Liang G, Lu R: A novel protein, Luman/CREB3 recruitment factor, inhibits Luman activation of the unfolded protein response. $\mathrm{Mol}$ Cell Biol 2008, 28(12):3952-3966.

79. Rodriguez I, Coto E, Reguero JR, Gonzalez P, Andres V, Lozano I, Martin M, Alvarez V, Moris C: Role of the CDKN1A/p21, CDKN1C/p57, and CDKN2A/ p16 genes in the risk of atherosclerosis and myocardial infarction. Cell Cycle 2007, 6(5):620-625.

80. Sotoodehnia N, Isaacs A, de Bakker PI, Dorr M, Newton-Cheh C, Nolte IM, van der Harst P, Muller M, Eijgelsheim M, Alonso A, et al: Common variants in 22 loci are associated with QRS duration and cardiac ventricular conduction. Nat Genet 2010, 42(12):1068-1076

81. Schwarz M, Spath L, Lux CA, Paprotka K, Torzewski M, Dersch K, KochBrandt C, Husmann M, Bhakdi S: Potential protective role of apoprotein J (clusterin) in atherogenesis: binding to enzymatically modified lowdensity lipoprotein reduces fatty acid-mediated cytotoxicity. Thromb Haemost 2008, 100(1):110-118.

82. $\mathrm{Xu} Y$, Johansson M, Karlsson A: Human UMP-CMP kinase 2, a novel nucleoside monophosphate kinase localized in mitochondria. J Biol Chem 2008, 283(3):1563-1571.

83. Ishiguro $H$, Tsunoda $T$, Tanaka T, Fujii $Y$, Nakamura $Y$, Furukawa $Y$ : Identification of AXUD1, a novel human gene induced by AXIN1 and its reduced expression in human carcinomas of the lung, liver, colon and kidney. Oncogene 2001, 20(36):5062-5066.

84. Pramanik K, Chun CZ, Garnaas MK, Samant GV, Li K, Horswill MA, North PE, Ramchandran R: Dusp-5 and Snrk-1 coordinately function during vascular development and disease. Blood 2009, 113(5):1184-1191.

85. Ferreira VP, Pangburn MK, Cortes $\mathrm{C}$ : Complement control protein factor $\mathrm{H}$ : the good, the bad, and the inadequate. Mol Immunol 2010, 47(13):2187-2197.

86. Swaminath $\mathrm{G}$ : Fatty acid binding receptors and their physiological role in type 2 diabetes. Arch Pharm (Weinheim) 2008, 341(12):753-761.

87. Kang JG, Sung HJ, Jawed SI, Brenneman CL, Rao YN, Sher S, Facio FM, Biesecker LG, Quyyumi AA, Sachdev V, et al: FOS expression in blood as a LDL-independent marker of statin treatment. Atherosclerosis 2010, 212(2):567-570.

88. Welch C, Santra MK, El-Assaad W, Zhu X, Huber WE, Keys RA, Teodoro JG, Green MR: Identification of a protein, GOS2, that lacks Bcl-2 homology domains and interacts with and antagonizes Bcl-2. Cancer Res 2009 69(17):6782-6789.

89. Hellerud C, Burlina A, Gabelli C, Ellis JR, Nyholm PG, Lindstedt S: Glycerol metabolism and the determination of triglycerides-clinical, biochemical and molecular findings in six subjects. Clin Chem Lab Med 2003, 41(1):46-55.

90. Heiber M, Marchese A, Nguyen T, Heng HH, George SR, O'Dowd BF: A novel human gene encoding a G-protein-coupled receptor (GPR15) is located on chromosome 3. Genomics 1996, 32(3):462-465.

91. Brandes RP, Kim D, Schmitz-Winnenthal FH, Amidi M, Godecke A, Mulsch A, Busse R: Increased nitrovasodilator sensitivity in endothelial nitric oxide synthase knockout mice: role of soluble guanylyl cyclase. Hypertension 2000, 35(1 Pt 2):231-236.

92. Johnson AD, Kavousi M, Smith AV, Chen MH, Dehghan A, Aspelund T, Lin JP, van Duijn CM, Harris TB, Cupples LA, et al: Genome-wide association meta-analysis for total serum bilirubin levels. Hum Mol Genet 2009, 18(14):2700-2710.

93. Mibayashi M, Martinez-Sobrido L, Loo YM, Cardenas WB, Gale M Jr: GarciaSastre A: Inhibition of retinoic acid-inducible gene I-mediated induction of beta interferon by the NS1 protein of influenza A virus. J Virol 2007, 81(2):514-524

94. Barrett JC, Clayton DG, Concannon P, Akolkar B, Cooper JD, Erlich HA, Julier C, Morahan G, Nerup J, Nierras C, et al: Genome-wide association study and meta-analysis find that over 40 loci affect risk of type 1 diabetes. Nat Genet 2009, 41(6):703-707.

95. Ohnesorge N, Viemann D, Schmidt N, Czymai T, Spiering D, Schmolke M, Ludwig S, Roth J, Goebeler M, Schmidt M: Erk5 activation elicits a vasoprotective endothelial phenotype via induction of Kruppel-like factor 4 (KLF4). J Biol Chem 2010, 285(34):26199-26210.
96. Rubinstein M, Idelman G, Plymate SR, Narla G, Friedman SL, Werner H: Transcriptional activation of the insulin-like growth factor I receptor gene by the Kruppel-like factor 6 (KLF6) tumor suppressor protein: potential interactions between KLF6 and p53. Endocrinology 2004, 145(8):3769-3777.

97. Andreoli V, Gehrau RC, Bocco JL: Biology of Kruppel-like factor 6 transcriptional regulator in cell life and death. IUBMB Life 2010, 62(12):896-905.

98. Romacho T, Azcutia V, Vazquez-Bella M, Matesanz N, Cercas E, Nevado J, Carraro R, Rodriguez-Manas L, Sanchez-Ferrer CF, Peiro C: Extracellular PBEF/NAMPT/visfatin activates pro-inflammatory signalling in human vascular smooth muscle cells through nicotinamide phosphoribosyltransferase activity. Diabetologia 2009, 52(11):2455-2463.

99. Weng YJ, Hsieh DJ, Kuo WW, Lai TY, Hsu HH, Tsai CH, Tsai FJ, Lin DY, Lin JA Huang CY, et al: E4BP4 is a cardiac survival factor and essential for embryonic heart development. Mol Cell Biochem 2010, 340(1-2):187-194.

100. Dehghan A, Yang Q, Peters A, Basu S, Bis JC, Rudnicka AR, Kavousi M, Chen $\mathrm{MH}$, Baumert J, Lowe GD, et al: Association of novel genetic Loci with circulating fibrinogen levels: a genome-wide association study in 6 population-based cohorts. Circ Cardiovasc Genet 2009, 2(2):125-133.

101. Dehghan A, Dupuis J, Barbalic M, Bis JC, Eiriksdottir G, Lu C, Pellikka N Wallaschofski $H$, Kettunen J, Henneman P, et al: Meta-analysis of genomewide association studies in $>80000$ subjects identifies multiple loci for C-reactive protein levels. Circulation 2011, 123(7):731-738.

102. Voight BF, Scott LJ, Steinthorsdottir V, Morris AP, Dina C, Welch RP, Zeggini E, Huth C, Aulchenko YS, Thorleifsson G, et al: Twelve type 2 diabetes susceptibility loci identified through large-scale association analysis. Nat Genet 2010, 42(7):579-589.

103. Lauc G, Essafi A, Huffman JE, Hayward C, Knezevic A, Kattla JJ, Polasek O, Gornik O, Vitart V, Abrahams $J$, et al: Genomics meets glycomics-the first GWAS study of human N-Glycome identifies HNF1alpha as a master regulator of plasma protein fucosylation. PLOS Genet 2010, 6(12): e1001256

104. Dorsam RT, Kunapuli SP: Central role of the P2Y12 receptor in platelet activation. J Clin Invest 2004, 113(3):340-345.

105. Rauch BH, Rosenkranz AC, Ermler S, Bohm A, Driessen J, Fischer JW, Sugidachi A, Jakubowski JA, Schror K: Regulation of functionally active P2Y12 ADP receptors by thrombin in human smooth muscle cells and the presence of P2Y12 in carotid artery lesions. Arterioscler Thromb Vasc Biol 2010, 30(12):2434-2442.

106. Peluso JJ, Liu X, Gawkowska A, Johnston-MacAnanny E: Progesterone activates a progesterone receptor membrane component 1-dependent mechanism that promotes human granulosa/luteal cell survival but not progesterone secretion. J Clin Endocrinol Metab 2009, 94(7):2644-2649.

107. Alfano D, Franco P, Vocca I, Gambi N, Pisa V, Mancini A, Caputi M, Carriero MV, laccarino I, Stoppelli MP: The urokinase plasminogen activator and its receptor: role in cell growth and apoptosis. Thromb Haemost 2005, 93(2):205-211.

108. Chavakis T, Kanse SM, May AE, Preissner KT: Haemostatic factors occupy new territory: the role of the urokinase receptor system and kininogen in inflammation. Biochem Soc Trans 2002, 30(2):168-173.

109. Oda E, Ohki R, Murasawa H, Nemoto J, Shibue T, Yamashita T, Tokino T, Taniguchi T, Tanaka N: Noxa, a BH3-only member of the $\mathrm{Bcl}-2$ family and candidate mediator of p53-induced apoptosis. Science 2000 288(5468):1053-1058.

110. Morton E, Macrae IM, McCabe C, Brown SM, White F: Identification of the growth arrest and DNA damage protein GADD34 in the normal human heart and demonstration of alterations in expression following myocardial ischaemia. Int J Cardiol 2006, 107(1):126-129.

111. Cipollone F, Fazia ML: COX-2 and atherosclerosis. J Cardiovasc Pharmacol 2006, 47(Suppl 1):S26-S36.

112. Cipollone F, Toniato E, Martinotti S, Mezzetti A: Genetic and molecular determinants of atherosclerotic plaque instability. Curr Vasc Pharmacol 2010, 8(4):545-552.

113. Min SH, Kim DM, Heo YS, Kim YI, Kim HM, Kim J, Han YM, Kim IC, Yoo OJ: New p53 target, phosphatase of regenerating liver 1 (PRL-1) downregulates p53. Oncogene 2009, 28(4):545-554.

114. Claudio JO, Zhu YX, Benn SJ, Shukla AH, McGlade CJ, Falcioni N, Stewart AK: HACS1 encodes a novel SH3-SAM adaptor protein differentially 
expressed in normal and malignant hematopoietic cells. Oncogene 2001, 20(38):5373-5377.

115. Zhu YX, Benn S, Li ZH, Wei E, Masih-Khan E, Trieu Y, Bali M, McGlade CJ, Claudio JO, Stewart AK: The SH3-SAM adaptor HACS1 is up-regulated in B cell activation signaling cascades. J Exp Med 2004, 200(6):737-747.

116. Joost HG, Bell GI, Best JD, Birnbaum MJ, Charron MJ, Chen YT, Doege H, James DE, Lodish HF, Moley KH, et al: Nomenclature of the GLUT/SLC2A family of sugar/polyol transport facilitators. Am J Physiol Endocrinol Metab 2002, 282(4):E974-E976.

117. Charniot JC, Sutton A, Bonnefont-Rousselot D, Cosson C, Khani-Bittar R, Giral P, Charnaux N, Albertini JP: Manganese superoxide dismutase dimorphism relationship with severity and prognosis in cardiogenic shock due to dilated cardiomyopathy. Free Radic Res 2011, 45(4):379-388.

118. Valdez AC, Cabaniols JP, Brown MJ, Roche PA: Syntaxin 11 is associated with SNAP-23 on late endosomes and the trans-Golgi network. J Cell Sci 1999, 112(Pt 6):845-854.

119. Franke A, McGovern DP, Barrett JC, Wang K, Radford-Smith GL, Ahmad T, Lees CW, Balschun T, Lee J, Roberts R, et al: Genome-wide meta-analysis increases to 71 the number of confirmed Crohn's disease susceptibility loci. Nat Genet 2010, 42(12):1118-1125.

120. Chen R, Stahl EA, Kurreeman FA, Gregersen PK, Siminovitch KA, Worthington J, Padyukov L, Raychaudhuri S, Plenge RM: Fine mapping the TAGAP risk locus in rheumatoid arthritis. Genes Immun 2011, 12(4):314-318.

121. Eyre S, Hinks A, Bowes J, Flynn E, Martin P, Wilson AG, Morgan AW, Emery P, Steer S, Hocking $\sqcup$, et al: Overlapping genetic susceptibility variants between three autoimmune disorders: rheumatoid arthritis, type 1 diabetes and coeliac disease. Arthritis Res Ther 2010, 12(5):R175.

122. Esemuede N, Lee T, Pierre-Paul D, Sumpio BE, Gahtan V: The role of thrombospondin-1 in human disease. J Surg Res 2004, 122(1):135-142.

123. Sargiannidou I, Qiu C, Tuszynski GP: Mechanisms of thrombospondin-1mediated metastasis and angiogenesis. Semin Thromb Hemost 2004, 30(1):127-136.

124. Stoll LL, Denning GM, Weintraub NL: Endotoxin, TLR4 signaling and vascular inflammation: potential therapeutic targets in cardiovascular disease. Curr Pharm Des 2006, 12(32):4229-4245.

125. An H, Qian C, Cao X: Regulation of Toll-like receptor signaling in the innate immunity. Sci China Life Sci 2010, 53(1):34-43.

126. Perry SV: Vertebrate tropomyosin: distribution, properties and function. J Muscle Res Cell Motil 2001, 22(1):5-49.

127. Waterworth DM, Ricketts SL, Song K, Chen L, Zhao JH, Ripatti S, Aulchenko YS, Zhang W, Yuan X, Lim N, et al: Genetic variants influencing circulating lipid levels and risk of coronary artery disease. Arterioscler Thromb Vasc Biol 2010, 30(11):2264-2276.

128. Denny JC, Ritchie MD, Crawford DC, Schildcrout JS, Ramirez AH, Pulley JM, Basford MA, Masys DR, Haines JL, Roden DM: Identification of genomic predictors of atrioventricular conduction: using electronic medical records as a tool for genome science. Circulation 2010, 122(20):2016-2021.

129. Ichimura T, Watanabe S, Sakamoto Y, Aoto T, Fujita N, Nakao M: Transcriptional repression and heterochromatin formation by MBD1 and MCAF/AM family proteins. J Biol Chem 2005, 280(14):13928-13935.

130. Fu C, Turck CW, Kurosaki T, Chan AC: BLNK: a central linker protein in B cell activation. Immunity 1998, 9(1):93-103.

131. Bantscheff M, Hopf C, Savitski MM, Dittmann A, Grandi P, Michon AM, Schlegl J, Abraham Y, Becher I, Bergamini G, et al: Chemoproteomics profiling of HDAC inhibitors reveals selective targeting of HDAC complexes. Nat Biotechnol 2011, 29(3):255-265.

132. Arming S, Wipfler D, Mayr J, Merling A, Vilas U, Schauer R, SchwartzAlbiez R, Vlasak R: The human Cas1 protein: a sialic acid-specific Oacetyltransferase? Glycobiology 2011, 21(5):553-564.

133. Marat AL, McPherson PS: The connecdenn family, Rab35 guanine nucleotide exchange factors interfacing with the clathrin machinery. J Biol Chem 2010, 285(14):10627-10637.

134. Akerblad P, Mansson R, Lagergren A, Westerlund S, Basta B, Lind U, Thelin A, Gisler R, Liberg D, Nelander $S$, et al: Gene expression analysis suggests that EBF-1 and PPARgamma2 induce adipogenesis of $\mathrm{NIH}-3 \mathrm{~T} 3$ cells with similar efficiency and kinetics. Physiol Genomics 2005, 23(2):206-216.

135. Boyd RS, Adam PJ, Patel S, Loader JA, Berry J, Redpath NT, Poyser HR, Fletcher GC, Burgess NA, Stamps AC, et al: Proteomic analysis of the cell- surface membrane in chronic lymphocytic leukemia: identification of two novel proteins, BCNP1 and MIG2B. Leukemia 2003, 17(8):1605-1612.

136. Davis RS, Wang YH, Kubagawa H, Cooper MD: Identification of a family of Fc receptor homologs with preferential B cell expression. Proc Natl Acad Sci USA 2001, 98(17):9772-9777.

137. Chureau C, Chantalat S, Romito A, Galvani A, Duret L, Avner P, Rougeulle C: Ftx is a non-coding RNA which affects Xist expression and chromatin structure within the X-inactivation center region. Hum Mol Genet 2011, 20(4):705-718.

138. Fredriksson R, Hoglund PJ, Gloriam DE, Lagerstrom MC, Schioth HB: Seven evolutionarily conserved human rhodopsin $\mathrm{G}$ protein-coupled receptors lacking close relatives. FEBS Lett 2003, 554(3):381-388,

139. Tano K, Mizuno R, Okada T, Rakwal R, Shibato J, Masuo Y, ljiri K, Akimitsu N: MALAT-1 enhances cell motility of lung adenocarcinoma cells by influencing the expression of motility-related genes. FEBS Lett 2010, 584(22):4575-4580.

140. Favre J, Gao J, Zhang AD, Remy-Jouet I, Ouvrard-Pascaud A, Dautreaux B, Escoubet B, Thuillez C, Jaisser F, Richard V: Coronary endothelial dysfunction after cardiomyocyte-specific mineralocorticoid receptor overexpression. Am J Physiol Heart Circ Physiol 2011, 300(6):H2035-H2043.

141. Aksoy P, Zhu MJ, Kalari KR, Moon I, Pelleymounter LL, Eckloff BW, Wieben ED, Yee VC, Weinshilboum RM, Wang L: Cytosolic 5'-nucleotidase III (NT5C3): gene sequence variation and functional genomics. Pharmacogenet Genomics 2009, 19(8):567-576.

142. Jiang Y, Scott KL, Kwak SJ, Chen R, Mardon G: Sds22/PP1 links epithelial integrity and tumor suppression via regulation of myosin II and JNK signaling. Oncogene 2011, 30(29):3248-3260.

143. Callebaut I, de Gunzburg J, Goud B, Mornon JP: RUN domains: a new family of domains involved in Ras-like GTPase signaling. Trends Biochem Sci 2001, 26(2):79-83.

144. Wen J, Huang S, Rogers H, Dickinson LA, Kohwi-Shigematsu T, Noguchi CT: SATB1 family protein expressed during early erythroid differentiation modifies globin gene expression. Blood 2005, 105(8):3330-3339.

145. Massague J: TGF-beta signal transduction. Annu Rev Biochem 1998, 67:753-791.

146. Bednarek AK, Keck-Waggoner CL, Daniel RL, Laflin KJ, Bergsagel PL, Kiguchi K, Brenner AJ, Aldaz CM: WWOX, the FRA16D gene, behaves as a suppressor of tumor growth. Cancer Res 2001, 61(22):8068-8073.

doi:10.1186/2043-9113-2-6

Cite this article as: Masud et al:: Gene expression profiling of peripheral blood mononuclear cells in the setting of peripheral arterial disease. Journal of Clinical Bioinformatics 2012 2:6.

\section{Submit your next manuscript to BioMed Central and take full advantage of:}

- Convenient online submission

- Thorough peer review

- No space constraints or color figure charges

- Immediate publication on acceptance

- Inclusion in PubMed, CAS, Scopus and Google Scholar

- Research which is freely available for redistribution

Submit your manuscript at www.biomedcentral.com/submit
Ciomed Central 